\author{
THE EFFECT OF ILLICIT \\ DRUG USE ON THE LABOR SUPPLY \\ OF YOUNG ADULTS
}

Robert Kaestner

Working Paper No. 4187

\author{
NATIONAL BUREAU OF ECONOMIC RESEARCH \\ 1050 Massachusetts Avenue \\ Cambridge, MA 02138 \\ October 1992
}

I would like to thank Randy Filer, Jeff Grogger, Michael Grossman, Deborah Haas-Wilson, Cordelia Reamers, and Gary Zarkin for their helpful comments and suggestions. I also would like to thank Andrea Lynch who provided excellent research assistance. This paper is part of NBER's research program in Health Economics. Any opinions expressed are those of the author and not those of the National Bureau of Economic Research. 
NBER Working Paper \#4187

October 1992

\title{
THE EFFECT OF ILLICIT \\ DRUG USE ON THE LABOR SUPPLY \\ OF YOUNG ADULTS
}

\begin{abstract}
This paper analyzes the effects of illicit drug use on the labor supply of a sample of young adults using data from the National Longitudinal Survey of Youth. The paper investigates whether the frequency and timing of marijuana and cocaine use are systematically related to labor supply, and presents both cross sectional and longitudinal estimates. The cross sectional results are consistent with those of previous researchers, and suggest that illicit drug use has large, negative effects on labor supply. The longitudinal results, however, suggest that illicit drug use does not have a significant adverse impact on labor supply.
\end{abstract}

Robert Kaestner

Department of Economics

Rider College

Lawrenceville, NJ 08648

and NBER 


\section{Introduction}

There is widespread concern over the negative effects of illicit drug use on the workforce. Hundreds of companies in the U.S. have developed extensive alcohol and drug abuse programs alternately aimed at prevention, detection and treatment of employees who use illicit drugs (Hayghe 1991 ). The federal government has also been quite active in their efforts to control illicit drug use, particularly in the workplace. The Drug Free Workplace Act of 1988 requires federal government contractors to maintain drug free workplaces, and executive order 12564 requires ail federal agencies to establish drug free workplace policies. There is a general concern in the country that the ability of our workers is being seriously impaired by iliicit drug use.

One of the most often cited results of illicit drug use is the inconsistency of labor force participation, including chronic absenteeism, although there have been few systematic studies of the labor market effects of illicit drug use. Johnson and Herring (1989) find that illicit drug use among young adults leads to delayed entry into the labor market. Kandel and Davies (1990) using data from the National Longitudinal Survey of Youth (NLSY), and Kandel and Yamaguchi (1987) using regional data, find that illicit drug use is positively correlated with weeks unemployed and increased job mobility (e.g. quits) among young adults. Using a somewhat older and more limited sample, White et. al. (1988) find no effect of illicit drug use on labor force participation. Finally, uging a novel experimental design, Kagel et. al. (1980) report no significant effects of marijuana use on hours of work of young adults. Most of these studies suggest that among young adults, drug users work less hours than non-users over the course of the year. In addition, Gleason et. al. (1991) report that 7 of respondents in the NLSY reported drug use on the job as of 1984. Thus, it is possible that drug users will be devoting less actual time to work, even if they are technically working the same amount of 
nours as comparable non-users.

If llicit drug use is in fact responsible for a reduction in the labor supply of individuals, the economic implications of such an occurrence are significant. The reduced labor market experience of drug users will result in a decrease in the amount of worker on-the-job raining, and other human capital building activities. The lower levels of human capical accumulation will decrease the productivity of the U.S. workforce. The decline in productivity will reduce the competitiveness of U.S. workers, tncrease production costs, and lead to diminished living standards. These are the types of considerations that underlie the "war on drugs", and the explosion in employer concern over illicit drug use.

This paper analyzes the effects of illicit drug use on the labor supply of a sample of young adults using data from the National Longitudinal Survey of youth (NLSY). In particular, the paper investigates whether the frequency and timing of marijuana and cocaine use are systematically related to the quantity of labor supplied. As was noted above, there have been very few systematic studies of the effects of illicit drug use in the labor market, and even fewer based on economic theory. Thus, this paper makes a contribution in two ways. First, it outlines the relevant economic theory, and applies it to the problem of illicit drug use and labor supply. Second, it useg micro-data to obtain both cross sectional and longitudinal estimates of the effects of illicit drug use on labor supply, and addresses several previously ignored empirical problems. The cross sectional results of this paper are consistent with the findings of previous researchers, and suggest that illicit drug use has large negative effects on labor supply. The longitudinal results, however, suggest that illicit drug use does not appear to have a significant adverse impact on the hours of work supplied to the market. In particular, it is found that the effect of illicit drug use on labor supply is quite variable, and that there does not appear to be a common experience with regard to the relationship between illicit 
drugs and labor supply.

The balance of the paper will be divided into the following parts. The next section presents a simple theoretical model of drug use and 1 abor supply. This section sets forth a framework of analysis, and specifies the ways in wich drug use can be incorporated into the more general theory of consumer behavior. The third section describes the empirical model used to estimate the effects of illicit drug use on labor supply. This section is followed by a description of the data, including sample design and important variable definitions. A presentation of the results will follow the data section, and the paper will end with a summary of the main findings.

II. Analytical Model of Drug Use and Labor Supply

The most straightforward way in which to incorporate illicit drug use into a labor supply model is to treat illicit drugs as a consumption good that enters into the ueility function. Following Becker and Murphy (1988), an age specific utility function of the following general form can be specified;

$$
U_{1}=U\left(L_{1}, D_{1}, S_{1}, x\right),
$$

where $L$ is the amount of leisure, $D$ is the quantity of illicit drugs, $S$ is the stock of drug consumption capital, $x$ is a composite good representing other consumption, and $t=1$ to $T$ indexes age. The inclusion of the stock of drug consumption capital in the utility function is a distinguishing feature of the current problem, and is similar to models of consumer durable goods and habit forming consumption (Deaton and Muellbauer 1980). Presently, it is not assumed that drugs are a durable good, but rather that they are potentially an addictive good. An addictive good is defined as any good in which past and/or future consumption levels influence current consumption levels (Becker and Murphy 1988, Grossman 1991). Given 
these preferences, a cost function can be defined that indicates the minimum cost of obtaining a certain level of utility given prices, or

$$
C_{1}=c\left(W_{1}, V_{1}, P_{v}: U_{1}=u\left(L_{1}, D_{1}, S_{1}\right)\right)
$$

where $w$ is the wage, $V$ is the price of current drug consumption which consistg of two parts, the market price of illicit drugs and the user cost associated with the drug consumption capital, and $P_{v}$ is the price of other consumption. The reason for including the stock of drug consumption capital in the utility function is that current utility is affected by past drug use through a "learning by doing process" (Becker and Murphy 1988, p.677). Thus, the price of current drug use needs to reflect these learning by doing effects on utility." The compensated demand functions for leisure (L), and illicit drugs (D), can be obtained by differentiating equation (2) with respect to wages and the price of drugs. These demand functions will be a function of all prices and the level of utility. For example, the demand for leisure can be represented as follows;

$$
L_{1}=f\left(W_{1}, V_{1}, P_{x 1}, U_{1}\right)
$$

From an empirical point of view, equation (3) is somewhat limited, due to the fact that $v$, the price of current drug consumption, including the user cost associated with the drug consumption capital, is never observed, nor is the level of utility. A solution to this problem is to use the conditional cost function to represent preferences (Pollak 1969, Browning 1983, Browning and Meghir 1991). In the conditional cost function, illicit drugs and the stock of drug consumption capital are treated as conditioning variables that affect preferences, but are not of primary interest (8rowning 1983, Browning and Meghir 1991). The consumer minimizes the cost of achieving a certain level of utility given that the quantity of some goods (e.g. illicit drugs) are predetermined. Thus, 
equation (2) can be rewritten as follows;

$$
C_{1}=c\left(W_{1}, D_{:}, P_{11}: U_{1}=u\left(L_{1}, D_{1}, S_{1}\right)\right)
$$

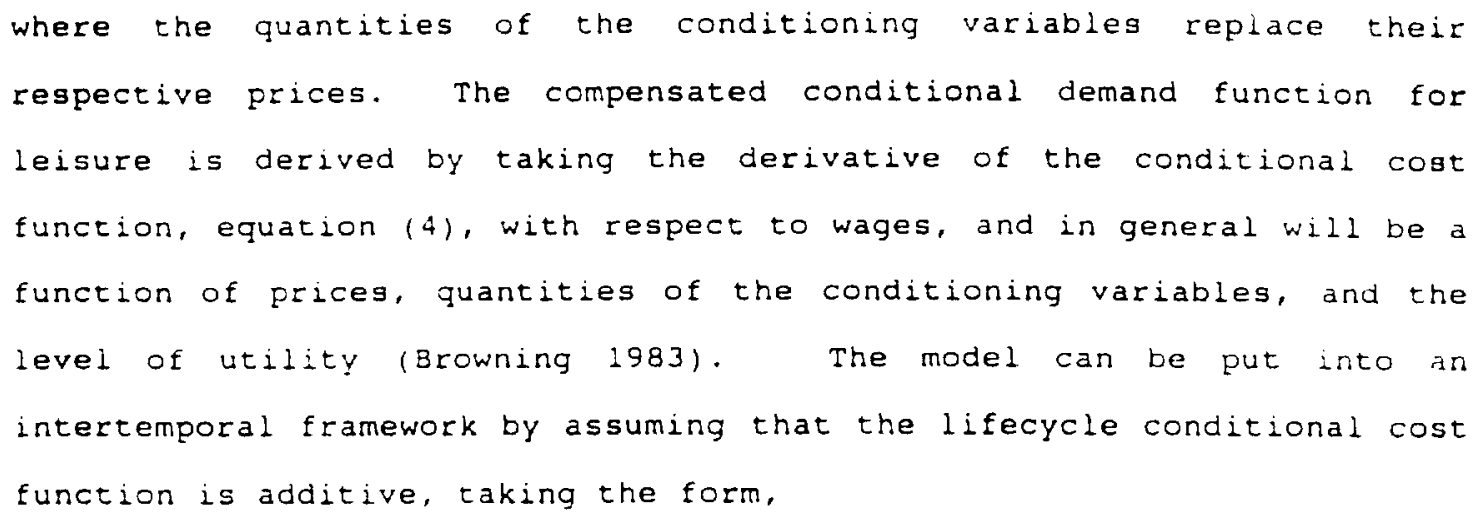

The additive nature of equation (5) implies that preferences are implicitly separable, and the level of utility, $U$, in equation (5) refers to Iifetime utility (Deaton and Muellbauer 1980). This specification is completely consistent with the idea that past consumption of illicit drugs affect current consumption, since each age specific conditional cost function includes the current quantity of illicit drugs which is determined by past and future consumption. Thus, equation (5) is consistent with the Becker and Murphy (1988) model of rational addiction. The age specific, compensated conditional demand functions are the derivatives of equation (5) with respect to prices. The demand for leisure would in general be of the following form;

$$
L_{1}=g\left(W_{1}, D_{1}, P_{x 1}, U\right),
$$

where $U$ is the level of lifetime utility. ${ }^{3}$ The demand for leisure, and labor supply functions embodied in equation (6), are a departure from the 
usual model of lifecycle labor supply found in the literature (Macurdy 1981. Heckman and Killingsworth 1986). In the typical lifecycle model, Erisch demand functions are specified that hold the marginal utility of wealth constant, as opposed to the level of lifetime utility found in equation (6). Empirically, the two models are identical, but interpretation of the effects of price changes are qualitatively different (Macurdy 1981, Browning, Deaton and Irish 1985). In the current case the utility compensated price effect would be estimated, as opposed to the marginal utility of wealth compensated effect, commonly referred to as the intertemporal effect (elasticity). Macurdy (1981) details the relationship between the two measures. The primary purpose of this paper is in identifying the effect of illicit drug use on labor supply, and thus, the distinction between which price effect is being estimated is not of paramount concern.

The use of conditional cost functions, and the resulting conditional demands, has several advantages in the current context, as noted by Browning and Meghir (1991). First, the conditional approach eliminates the need to specify the underlying model of the conditioning goods, which in this case are the current consumption of illicit drugs, and the stock of drug consumption capital. This is a real advantage given the complicated nature of the demand functions for addictive goods (Chaloupka 1991. Becker, Grossman and Murphy 1991). Second, the conditional approach is empirically valid even when individuals are at corner solutions, which is a common occurrence with regard to drug use. Thus, the need for a switching regression empirical framework is eliminated. Third, the conditional approach eliminates the need to use measures of the price of illicit drugs, which are expected to be of very poor quality, and difficult to accurately calculate due to the user cost component associated with the stock of drug consumption capital. Finally, since the primary purpose of this paper is to identify the effect, if any, of illicit drug use on labor supply, the conditional approach facilitateg the 
direct estimation of such an effect, as opposed to simply the sign and magnitude of the cross price effect.

What is the expected effect of illicit drug use on labor supply. Using the terminology associated with the hougehold production theory of Becker (1965), it seems appropriate to assume that drug use is a time intensive activity. Persons who consume drugs would be expected to have a preference for a more time intensive consumption bundle than comparable non-users. Given this assumption, we would expect drug users to supply less time to the market. In addition, since drug users are expected to have a higher rate of time preference, they would prefer current consumption, including leisure, to future consumption (Becker and Murphy 1988). A preference for current consumption would also lead to the canclusion that drug users would supply less time in the market (Ghez and Becker 1975). The current problem is very similar to the way in which children have been assumed to affect labor supply. The quantity of children are often entered into the labor supply function instead of the more appropriate (shadow) price of children (see Hotz and Miller (1988) for an exception)." Since child rearing is assumed to be a time intensive activity, particularly for females, the often observed negative effect of children on female labor supply is to be expected. Exactly the sane reasoning can be applied to the effects of drugs on labor supply. On the other hand, if drug use was a goods intensive activity, we would expect increased drug use to be positively related to labor supply. The production of "euphoria" to use the stigler and Becker (1977) label. might necessitate a much greater market input component (i.e drugs) than time (leisure) input.

In terms of the compensated conditional demand approach outlined above, an increase in illicit drug use will result in an increase or decrease in leisure, depending on whether leisure anc drugs are net complements or substitutes. Since it is a model of compensated demand, there is no income effect. It seems reasonable, although far from 
certain, to expect drug use and leisure to be complements, thus, the expectation is that drug use will decrease labor supply, and increase leisure.

The model outlined above is easily extended to the family. The utility function would then include all family members' (e.g. husband and wife) leisure and the quantity of drugg would refer to total household consumption of drugs.:

II. Empirical Model of Drug Use and Labor Supply

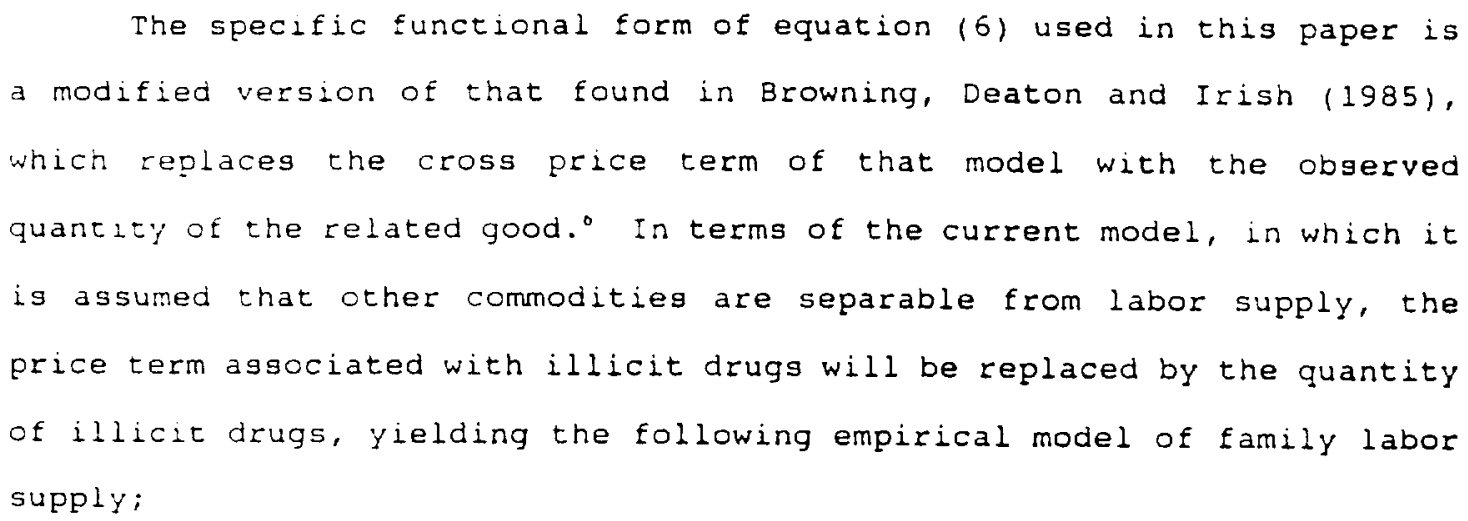

where everything is as defined previously, $H_{1}=T-L_{1}$ is the hours of work, OW, indexes the own or respondent's wage, SW, indexes the spouse's wage (in a family labor supply model), $z_{1}$ is a vector of exogenous variables, including among others the number of children of varioug ages, the respondent's age and education, the a's are parameters to be estimated, and $e$ is a stochastic error term. Equation (6a) is convenient to work with since lifetime utility, $U$, is invariant over time by definition, and as such can be eliminated through implementation of a fixed effect estimator. 
Both illicit drug use and the stock of drug consumption capital may be endogenous in equation (6a), and an appropriate estimation method for such circumstances needs to be implemented. In this paper, an instrumental variableg (IV) approach will be used. The conditional demand framework eliminates the need of specifying the underlying model determining illicit drug use and the stock of drug consumption capital, and as long as some identifying variables (assumptions) can be found, consistent estimateg of the parameters can be derived.

Before turning to the problems of measurement error and sample selection, several additional points relating to equation $(6$ a) need to be addressed. The wage of the spouse, $S W_{1}$, is not observed in the data, but their hours of work are observed. Given this circumstance, it would seem reasonable to replace the wage of the spouse by the quantity of hours worked, consistent with the treatment of drug use, and the idea of conditional demand functions. The spouse's hours, however, would then be an endogenous variable in the model, and some type of two stage procedure would need to be implemented. Alternatively, equation (6a) could be estimated as a semi-reduced form, where the age and education of the spouse are included in the vector $z_{1}$, thereby making the identification of the structural parameter a: impossible. The age and education of the spouse are the primary determinants of the spouse's wage. Since the main purpose of the paper is to identify the effects of drug use, and not to estimate the structural cross wage effect, equation (6a) will be estimated as a semi-reduced form.' A similar argument to that used for the cross wage could also be made in regard to the own wage effect. In this case, however, it is somewhat more important to estimate the structural parameter because drug use is also a determinant of the own wage (Kaestner 1991). Omitting the own wage from the model would regult in the drug use measures capturing both the direct and indirect, through the wage, effects of such uge on labor supply."

Equation ( 6 a) still suffers from the usual empirical problem 
assoclated with corner solutions due to non-workers, and will have to be estimated using appropriate methods. in individual's hours of work and market wage are only observed for those who work, and thus, equation (6a) will be estimated for a sample of employed individuals. As is well known, this type of "sample selection" criteria tends to result in biased estimates of the true parameters (Heckman 1976). In this paper, the two stage procedure due to Heckman $(1976,1979)$ will be implemented. The first stage consists of estimating a reduced form probit model of labor force participation, while the second stage, is the egtimation of an ols regression of labor supply for workers only, including the inverse mills ratio derived from the first stage.

Given the data that will be used in the analysis, both the wage and guantity (i.e frequency) of drug use might be expected to be measured with error. Thus, it is appropriate to use some type of instrumental variables in place of these measures. In addition, since drug use is also possibly endogenously determined in the model, the use of an instrumental variables technique to estimate drug use will also be an appropriate solution for the endogeneity problem. The primary instruments that will be used to egtimate the wage will be the individuals age, actual past labor market experience, education, and score on the armed forces qualification test." The instruments that are used to egtimate the drug use measures are several personal and family characteristics such as household composition at age 14, frequency of religious attendance in 1979, and a measure of their perceived self esteem. ${ }^{10}$ The wage and drug use are also expected to be simultaneously determined, and thus, the regressions that estimate both of these measures will be reduced form estimates (Kaestner 1991 ).

The model represented by equation (6a) will be estimated on two separate years of cross sectional data, 1984 and 1988 , and on a panel of data consisting of the two cross sections. Estimation using the limited panel will allow for the identification of the unobserved fixed effect in the model, which is potentially quite important. The cross sectional 


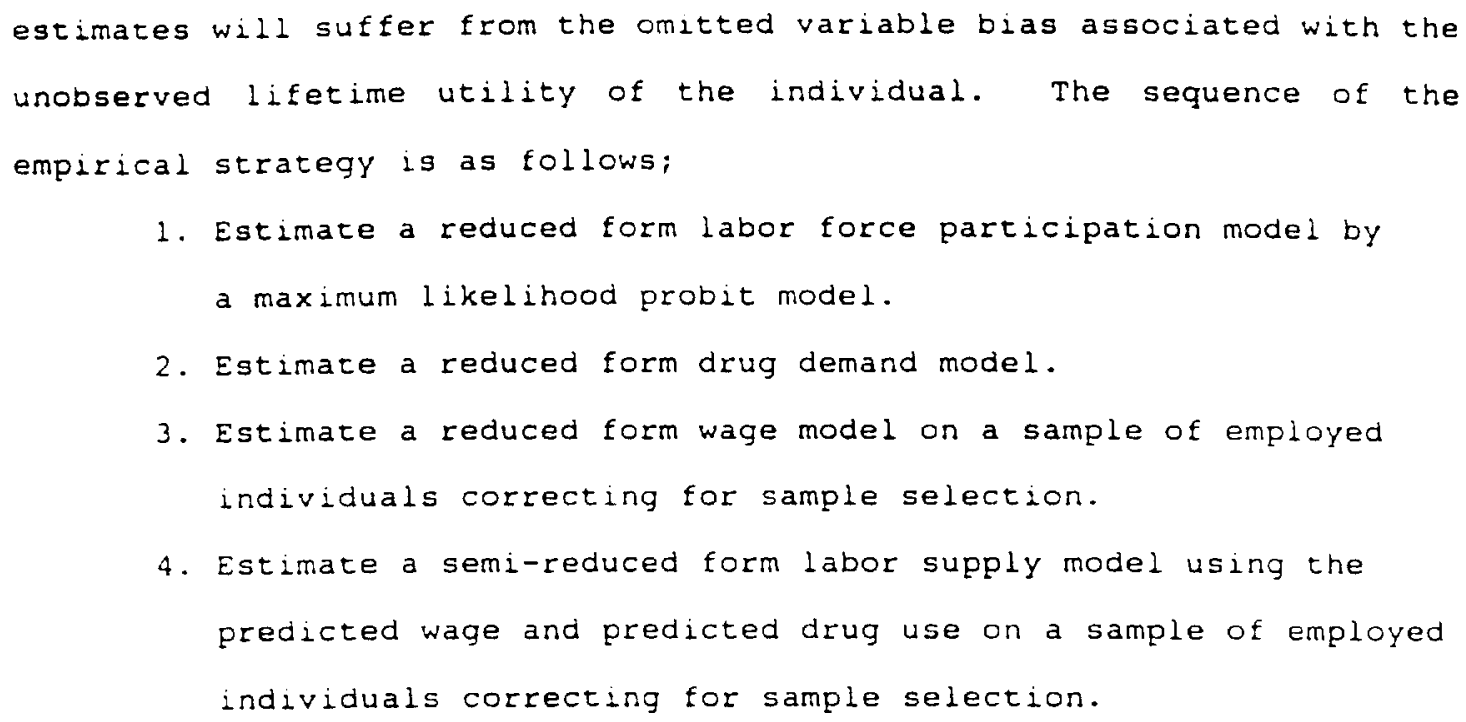

The empirical strategy is identical for the cross sectional and panel data estimates. For the panel data estimates, however, the sample selection criteria is whether or not the individual worked in both of the two separate years that make up the panel. Consistent with this selection criteria, two separate probit models will be used to derive the appropriate correction term for each year, and both terms entered into the labor supply regression."

As the previous two sections have detailed, the empirical implementation of a labor supply model including a potentially addictive good like illicit drugg is quite complex. Several theoretical and statistical assumptions have been made that impose strong restrictions on the model. Several of these assumptions have been previously shown to noticeably alter the egtimates and interpretation of such models (Mroz 1987, Browning, Deaton and Irish 1985, Browning and Meghir 1991). Thus, to some extent the empirical analysis will necessarily be more of a descriptive summary, than a structural investigation. 


\begin{abstract}
The data used in the analysis come from the National Longitudinal Survey of Youth (NLSY) which is a longitudinal survey of the labor market experiences of young adults (Center for Human Resource Research 1990). The starting year of the survey was 1979 and included an initial sample of approximately 12500 youths aged 14-21 at that time. The survey has been updated each $\because$ ear since 1979 with a broadening array of purposes and questions. The data contain detailed information on a respondent's labor market experlence, family and personal background, and illicit drug use. Central to the purposes of this paper are the questions related to respondent's lllicit drug use. In 1984, and again in 1988 the respondent was asked questions about their lifetime and current use of several illicit drugs, most notably marijuana and cocaine.

The sample used in the analysis was selected based on the following criteria which were established to eliminate several sources of heterogeneity in the sample. The respondent had to be at least 21 years old in 1984, be living independently or with their parents, but not in jail or other temporary quarters (e.g. dormitory), and the respondent could not be enrolled in school, or have served in the military, at any time between 1984 and 1988. In addition, those observations with missing data were deleted. These restrictions resulted in a sample size of approximately 4200 individuals in 1984 , and 4100 individuals in 1988 . Descriptive statistics of the variables used in the analysis can be found in the appendix. All analyses were done separately by marital status and gender." Separating the analyses on the basis of marital status is appropriate due to the expected impact of other family member characteristics (e.g. wage) on the respondents labor supply.

The illicit drug use questions are limited in two major respects. First, as is pointed out in Mensch and Kandel (1988), there appears to be some underreporting in the NLSY 1984 wave, particularly with regard to
\end{abstract}


cocaine use. The exact nature of the underreporting is not known, but Mensch and Kandel (1988) suggest that underreporting is more common among relatively light users, compared to more heavy users of illicit drugs, and more pronounced among females and minorities. Although, the analysis accounts for a simple (i.e. random) type of measurement error, the underreporting issue remains a problem. The second problem related to the drug use questions, is the absence of a measurement of quantity of use; only the frequency of drug use is measured. Although frequency and quantity have been shown to be highly correlated, the two measures are clearly not equivalent (stein et. al. 1988). In fact, stein et. al. (1988) report that the quantity of drug use is a more powerful predictor of problems associated with illicit drug use. In addition the frequency of use was interval coded with relatively large groupings (see table 1 ). This fact results in a more complex estimation strategy. As was noted above, instruments for the drug variables are obtained from auxiliary regressions, and given that the data on the frequency of drug use are discrete, simple oLs estimates will not be appropriate.

Table 1 is a frequency distribution of illicit drug use for the sample under examination, and presents the data by gender and marital status. As Mensch and Kandel (1988) have suggested, there appears to be some underreporting of drug use in the NLSY 1984 data, and the interested reader can see their work for more on this point. One finding of note in table 1 is the relatively large increase between 1984 and 1988 in the percentage of respondents reporting some lifetime use of cocaine. In 1984 about 15.7 of the married male sample and 8.9 of the married female sample report some prior cocaine use, and by 1988 these same figures are 26.6 and 16.98 . The same pattern can be observed for the sample of single individuals. The increase in the initiation into cocaine use over this age range is consistent with previous studies (Kandel and Logan 1984, Raveis and Kandel 1987). The surprising finding is that the number of respondents who have used cocaine in the past year has decreased over 


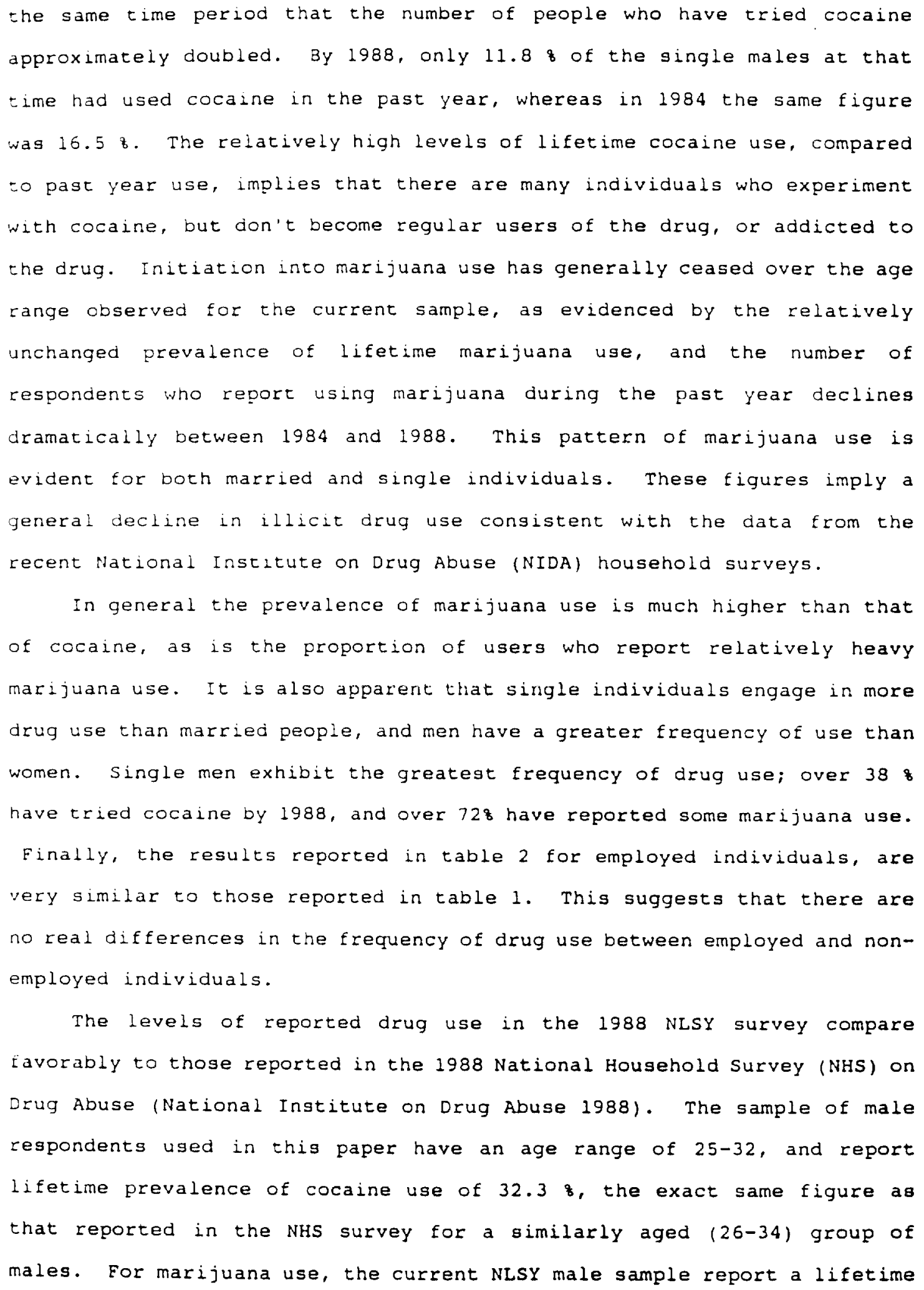


prevalence of use of $70.7 \%$, compared to 68.1 for the NHS. The same pattern is observed for the current NLSY sample of women, compared to those in the NHS. The women in the current sample report virtually identical prevalencies of cocaine use, 20.9 compared to 21.0 in the NHS, and a slightly greater prevalence of marijuana use, 60.2 a compared to 56.2 in the NHS. Thig finding raises questions about the extent of underreporting in the NLSY, and particularly whether there was in fact substantial underreporting in 1984, as suggested by Mensch and Kandel $(1988)$.

The measure of labor supply used in this paper is the number of hours worked in the past 12 months on all jobs reported during this period. The hours of work measure refers to the usual number of hours worked at the job(s) the respondent held during the past year. Thus, the measure ignores loss of work time to absenteeism, a potentially important source of hours variation among drug users. Labor force participation is defined as having worked for pay at some time during the pagt year. Table 3 contains the average annual hours of work, and average hourly wage rates, calculated from data on annual earnings and hours, by drug use category for the sample of employed respondents. The data are presented separately by marital status and gender. As expected, men work more hours and earn more per hour than the women, and married men work more than single men, while married women work less than single women. There does not appear to be any easily identifiable pattern to the data presented in table 3 that would suggest a systematic relationship between drug use and hourg of work, or drug use and wages. In fact, a regression of annual hours of work on dummy variables representing the different categories of illicit drug use, resulted in very few significant differences in hours worked across drug use categories for the four different male samples. There were no indications whatsoever that the relationship between hours worked and drug use was monotonic for the male samples. The same analysis for the female samples also resulted in only a few cases where hours of worked 
differed significantly by the frequency of drug use, and no case where the relationship was monotonic. Similar analyses were carried out on hourly wage rates, and the results indicated several significant differences, particularly for females, but still relatively few given the number of posszibities.

A variety of measures of illicit drug use were used in the analysis. Two linear measures of the lifetime frequency of illicit drug use were used; one measure took on values ranging from 0 to 4 , corresponding to the coding scheme used in the survey, and which is listed in table 1 , and the other used the midpoints of the intervals used by the survey to code drug responses. A series of dumy variables were also created to represent the frequency of lifetime lbicit drug use. For marijuana, the categories were the following, no use, 1-39 times, and 40 or more timeg of use. For cocaine, the categories were no use, $1-9$ times, and 10 or more times of use. The differences in the way the data were collapsed reflect the differences in the distribution of users across the drug typeg. In addition, a dummy variable indicating membership in the relatively higher drug use categories was used separately. A measure of past year use of illicit drugs was also used in the analysis. The only information in the data was whether or not the person used illicit drugs in the past year, and the variable was coded as a dummy variable with one indicating past year use.

The rest of the variables used in the analysis are somewhat standard, except for experience, and several of the variables used to predict drug use. Experience is the actual experience, and is the sum of actual weeks worked since 1975. As predictors of drug use, several personal and family background measures were included in the analysis, namely; a respondents score on a series of questions relating to self esteem (ESTEEM) as measured in 1980, the respondents score on a series of questions measuring an individuals feeling of control over the world (ROTTER) as measured in 1980, the frequency of religious attendance (RELIGION) prior to 1979, and 
the number of illegal acts (ILLACT) committed prior to 1980. Details of the questions that constitute these variables can be found in the NLS handbook (Center for Human Resources 1990).

\section{Cross Sectional Estimates}

The empirical strategy is to estimate reduced form models of labor force participation, drug use, and wages, in order to obtain their respective predicted values, and to use these predicted values as instruments for the actual value in a semi-reduced form labor supply model, estimated for persons with positive hours. 't The predicted value of illicit drug use was obtained in a variety of ways, corresponding to the particular form of drug use involved. The predicted value for the linear measures of lifetime use was obtained by an ols regression, the predicted value of the dummy variables representing lifetime use were obtained by an ordered probit procedure, and the predicted value of current use was obtained from a binary probit regression. In the dummy variableg case, the predicted probability of being in a certain category was used in place of the actual value. The predicted wage was obtained by ols methods corrected for sample selection.

In keeping with the tradition found in the previous literature, a meagure of non-earned income (OTHER INC) was also included in the cross sectional analyses. ${ }^{s}$ This variable measures all other types of income besides that from wages and salary, most important of which is spouse and/or family income. This variable is subject to both measurement error and endogeneity problems, and as such was instrumented for using the full set of exogenous variables. The cross sectional estimates will still be biased, however, due to sources of unobserved heterogeneity in the sample, the most important of which is the level of lifetime utility.

Table 4 containg the parameter estimates relating to illicit drug use from a labor supply model for males, estimated on cross sectional data 
from 1984 and 1988 . The full set of parameter estimates from a representative model can be found in the appendix. Three separate samples were used, a combined sample of married and single males, and separate samples chosen on the basis of marital status. When estimating the labor supply model using the combined sample, variables related to the respondent's spouse, and the variables measuring the number of children were interacted with a marriage dummy variable. In the reduced form regressions used to obtain the instrumental variables of wages and drug use, the marriage dumny variable was also interacted with labor market experience, and a dummy rariable indicating whether or not the person lived at home. For each sample, five separate models were estimated using one of the different measures of drug use; two linear measures of lifetime use, a set of dummy variables representing different levels of lifetime use, a dummy variable indicating relatively heavy use, and a dumy varbable indicating current use. The measure of lifetime drug use, which may include current use, and current drug use were not entered together in the same model, due to severe problems of multicollinearity. The actual values of all the drug measures are highly correlated, with gimple correlations of between .3 and .7 , and the predicted values of all the measureg are obtained with the same set of regressors. The problem of multicollinearity is also the explanation for why the models are estimated separately by type of illicit drug. Even when entered into the model separately, the set of dumny variables summarizing lifetime drug use are highly collinear; those with a high probability of being in category 1 also have a high probability of being in category 2, particularly for cocaine. The instability of the parameter estimates associated with these measures, and their large standard errors reflect the presence of severe multicollinearity.

The results presented in table 4 indicate that for married males, marijuana use appears to be associated with lower levels of labor supply in both 1984 and 1988. For example, those married men who have used 
marijuana 40 or more timea in their life, are expected to work between 503 (model 3) and 587 (model 4) hours less per year than comparable men using the 1984 estimate, or between 342 and 339 hours less per year using the 1988 estimate. For those males who have used marijuana in the past year as of 1988, they are expected to work 441 less hours than comparable nonusers. The effect of past year use is not significant in 1984, although it is negative and relatively large. Among single men, marijuana use appears to have a significant negative impact only in 1988, although many of the point estimates in 1984 are negative. In particular, those single men who currently use marijuana are expected to work about 879 hours less per year than similar men using the 1988 estimate. In general, it appears that increased frequency of use of marijuana is associated with lower levels of labor supply for men, with larger and more significant effects for married as opposed to single men, and in 1988 as compared to 1984. The large, and significantly negative impacts of current marijuana use in 1988 contrasts sharply with the impact of current marijuana use in 1984. There is very little initiation into marijuana use during this period, so current users are also past users, meaning that these people are not simply experimenting with use of this drug. Thus, the people in this category are more likely to be continuous, and serioug marijuana users, and the negative impact of such use is substantial.

The results related to the frequency of cocaine use are contained in the bottom half of table 4. For the 1984 sample, there does not appear to be any significant impact of cocaine use on the hours of work for males. This conclusion is reversed, however, by 1988 , and cocaine use is associated with less hours of work for both married and single men. For example, using the estimates from model 2, a married male who has used cocaine 20 times is expected to work 230 hourg lesg than a similar male who is a non-user. The same figure among single men would be 112 hours. As was the case for marijuana use, by 1988 , current male users of cocaine are expected to work many fewer hours than similar non-users. For married 
males, the figure is 819 hours, and for single men, the figure is 1096 hours. These are substantial effects given that the mean hours of work in the respective samples are approximately 2200 and 2000 . Although there is a substantial amount of initiation into cocaine use during this period, a larger proportion of current users in 1988 are expected to be continuous users, and to be more serious in their use.

Table 5 lists the results for the female samples, and is similar to table 4 in presentation. Examining the results presented in the top half of table 5, it appears that increased marijuana use is only significantly related to hours of work for the sample of single women in 1988 . Among this sample, those who used marijuana in the past year are expected to work 522 hours less than similar non-users. A single women who has used marijuana 40 or more $\tau$ imes in their life is expected to work between 587 (model 3) and $5: 8$ (model 4) hours less than a non-user. The bottom half of table 5 lists the results for cocaine use for the female sample. The only significant result among these estimates is for current or past year cocaine use among single women in 1988, and this is only marginally significant at the .10 level.

The parameter estimates associated with the other variables in the model are similar to previous estimates found in the literature. The female uncompengated own wage elasticity evaluated at the mean number of hours was in the .4 to .5 range in 1984 , and. 1 to .3 range in 1988 for the different samples. All of the wage estimates were highly significant. The presence of young children resulted in a significantly lower level of labor supply for women, and the effect of non-earned income on female labor supply was always insignificantly different from zero. Among the male samples, the own wage uncompensated elasticity was between .35 and .45 in 1984, and approximately .3 in 1988. The estimates that these elasticities were derived from were all statistically significant. The presence of children had no significant impact on male labor supply, and non-earned income was negative and significant only for the married male 
sample in 1984.

\section{Panel Data Estimates}

As suggested above, the presence of important unobserved individual characteristics, such as the level of lifetime utility, may cause the crosg sectional egtimates to be biased. In order to account for thege unobserved effects, the labor supply model represented by equation (6a) was re-estimated using a limited panel of data formed from the two cross sections of 1984 and 1988. The empirical estimateg were obtained from a model of first differences which will yield unbiased estimates if the unobserved characteristics, and their effects, are time invariant. For illustrative purposes, the empirical model can be written as follows;

$$
H_{i 1}=b_{n}+b_{1} x_{i}+b_{2} D_{i t}+b_{2} U+e_{i 1}
$$

and,

$$
H_{11 \cdot 1}=a_{0}+a_{1} X_{i}+a_{2} D_{i-1}+b_{3} U+e_{i-1},
$$

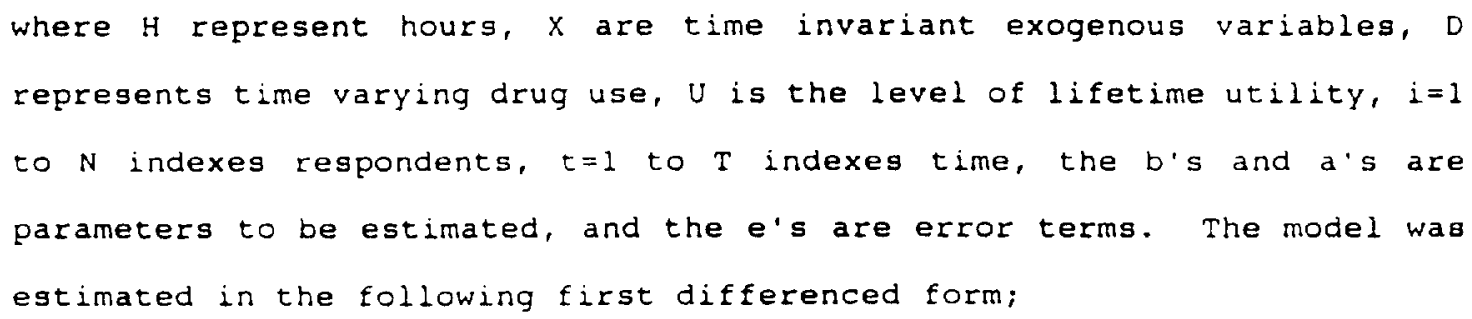

The above formulation imposes no restrictions on the estimates across years, except that the effect of the unobserved time invariant characteristic is constant. This unrestricted form also facilitates estimation of the predicted values used as instruments for the conditioning variables. For example, restricting the coefficients on drug 
use to be equal in equation ( 9 ), would necessitate that an instrument for the first difference of drug use be obtained. Since drug use is often cimeg a discrete measure, this would necessitate estimating a non-linear, fixed effect type of model which is a non-trivial tagk, and subject to its own set of problems (Chamberlain 1984). As currently formulated, instruments for drug use and wages are obtained on the levels of these variables using both years (i.e. 1984 and 1988) exagenous variables.10 The empirical procedure incorporates the Heckman $(1976,1979)$ correction for sample selection due to the presence of non-workers. The problem is Ignored in the married male samples, since over 958 of all matched respondents work in both years. In the female samples, the selection correction consists of estimating two separate probits, calculating two separate inverse mills ratios, and including both correction terms in the regression.

Three samples of data were created from the original two cross sections. The first sample consists of individuals who were married in 1984, and who remained married to the same partner through 1988. The second sample consists of individuals who were single in 1984 and remained single through 1988. The last sample consists of all individuals present in both survey years with complete sets of data in each year. In this sample the spouse related variables are interacted with a marriage dummy variable corresponding to the formulations used in the cross sectional analysis. The sample selection criteria related to age, school enrollment and the military also applies to these longitudinal samples. Finally, only the linear measures of lifetime drug use, and the binary measures of current drug use are used in the analysis. The omission of the categorical measures of lifetime drug use from the analysis was based on the instability of the cross sectional results relating to this variable. In addition several other models which included the first differenced form of the drug use variables were estimated, two of which appear in table $6 .{ }^{18}$ These alternative specifications were used to test whether the 
results of table 6 are sensitive to the expected multicollinearity between the current (i.e 1988) level of drug use and its lagged value (i.e 1984). In general, the results were not very sensitive to the choice of specification. Table 6 lists the parameter estimates associated with the drug use measures of equation (9). The signs on the 1984 values of drug use have been reversed for ease of exposition, since the regression package assumes an additive form of the model.

Examining the results pertaining to males, the left half of table 6 , it can be seen that there does not appear to be a consistently significant relationship between marijuana use and hours of work. In contrast to the cross sectional estimates, the point estimates of the effect of increased lifetime use are positive, although the standard errors are quite large. For current or past year marijuana use, the results are insignificant, but negative for the sample of single respondents and the total sample, which includes those respondents changing marital status between the four years. Again, the standard errors of the estimates are quite large. In the case of cocaine use, the results are similar to those for marijuana in that the signs of the effects change across samples, and the estimates have relatively large standard errors. Significant negative effects are observed, however, for the measures of lifetime and current cocaine use among the total sample of respondents. The results of table 6 are quite disconcerting, and raise several questions. Theoretically, the effect of one type of drug use, say cocaine, should be consistent across marital status groups, although the nature of the relationship between illicit drugs and leisure could differ by drug type. The illicit drug under examination and leisure should be complements or substitutes regardlesg of an individual's marital status. If, however, the imprecise measure of drug use used in this paper is related to the true measure differently according to marital status, then the variability of the results is expected. A similar argument was pregented earlier as a possible explanation of the differences in the effects of current illicit drug use 


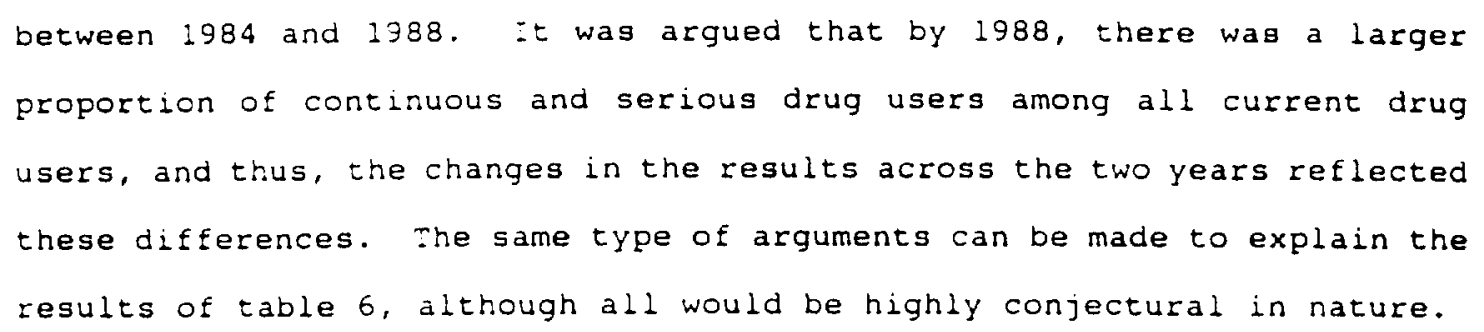

The right hand side of table 6 presents the longitudinal results for the female sample. As was the case for males, there is a good deal of variability in the results across drug use types and marital groups, and the standard errors are relatively large. Large negative, and often times significant effects of current marijuana and cocaine use are observed for the samples of single women and all women. Among the married women, however, current marijuana use is associated with large positive effects that approach common levels of statistical significance.

The findings with regard to the other variables in the model raise more doubts concerning the stability of the parameter estimates. They also raise questions about the commonly found way longitudinal estimateg of labor supply are obtained. It is almost universal to find that the empirical model restricts the coefficients on wages, and other important variables, to be time invariant. The current analysis presents a serious challenge to such methods. The parameter estimates associated with the wages of different years often differed dramatically from each other. The effect of time invariant variables also differed over time. The results associated with two representative models can found in the appendix.

\section{VI, Conclusion}

This paper has presented an empirical analysis of the effects of drug use on labor supply. Based on previous research, and the theoretical model currently presented, it was expected that drug use, would most likely have a negative impact on the hours of work supplied to the market, 
although a positive result could not be ruled out. The findings of this paper do not appear to be totally consistent with such an expectation. In the cross sectional cesults, the effect of illicit drug use on labor supply tended to be negative, and large in magnitude, particularly in 1988. The longitudinal estimates however, were less supportive of the expectation that illicit drug use would adversely affect labor supply. The parameter estimates were not in general negative, as in the cross section, and the variability of the estimates was much greater, than in the cross section. If, as is often argued in the literature, the longitudinal estimates are to be preferred, there appears to be no systematic effect of illicit drug use on labor supply, although among certain groups (samples) a significant negative effect is identified.

Taken at face vaiue, these results would have important policy implications. They would suggest that drug use among young adults is a highly idiosyncratic experience that has different effects on different people. There does not appear to be a common experience, and public policieg should reflect this fact if they are to be effective and cost efficient. The goal of policy would be to identify those individuals for which illicit drug use does become problematic, and further research is clearly needed in this area.

The regults of this paper should be viewed as preliminary. The current analysis suffers from several problems, most notable of which is poor measures of drug use. Only very crude measures of illicit drug uge were available, and the variability of the parameter estimates associated with drug use might very well be a function of this fact. The neoclassical model of labor supply, the starting point of this analysis, has also suffered from its share of empirical refutation. Several of the theoretical and statistical assumptions used throughout the paper are quite restrictive. These qualifications are important and necessitate more work in this area. 
$\therefore$ This point is best brought out by Hammermesh (1989) who analyzes the allocation of time at work using time diaries of workers.

2. Since changes in current consumption will alter the stock of drug consumption capital, the price of current consumption should include the effects of changes in the stock on utility. It is assumed that the changes in the stock of drug consumption capital are instantaneous.

3. The model is assuming perfect foresight, and neglects the case of uncertainty.

4. The use of the number of children of various ages in a labor supply model is very common, although widely acknowledged to be problematic. In this paper we follow the literature and ignore the endogeneity of children since the primary concern is in estimating the effects of drug use on labor supply.

5. An apparent drawback of the empirical model is that the measure of drug use actually used refers only to the respondent, and not the household. This implies that the drug use of one spouse is separable from the drug use of their partner.

6. The Browning Deaton and Irish (BDI) specification is for the Frisch demand functions derived from the consumer profit function, whereas in this paper the compensated demand function derived from the cost function is being used. The empirical specification, however, is identical, since the important element is to make the unobserved variable, in this case lifetime utility, enter additively into the model (BDI p.516). In the BDI (1985) model, the cross price term is the square root of the ratio of the price of drugs to the own wage, and thus, the substitution of the quantity of drugs for this term probably results in some misspecification of the model.

7. In addition, the use of the semi-reduced form provides a way to side step the problem of the spouse not working. In essence the age and education of the spouse are capturing the effects of the actual wage for working spouges and the reservation wage for non-working spouses. To the extent that the functional form of the empirical model becomes more ad-hoc, this procedure introduces the possibility of specification bias.

8. For the effects of drug use on wages see Kaestner (1991) who user the same data to estimate the relationship between drug use and wages.

9. Several of the variables will be entered into the regression in a quadratic form (experience) or as a series of dummy variables (education). In addition, several geographic measures and demographic variables will be included in the model.

10. See the appendix for a complete list of the variables used to predict drug use, as well as the variables used to predict the wage.

11. The estimation of the appropriate selection term is problematic for at least two reasons. First, the use of two independent probits is a less preferred strategy than using a bivariate probit, although in several models in which I was able to estimate the bivariate model the differences in the results were negligible. Second, and probably more important, the participation decision is also influenced by the life cycle aspects of the problem, and the cross sectional eatimates of the inverse mills ratio will be biased.

12. The 1988 survey limited the illicit drug use questions to include only marijuana and cocaine. 
13. imitirg tre sample on the basis of marriage gives rise to the possibility that the parameter estimates of the labor supply model will be biased if marriage and drug use are jointly determined. Empirically, tests of the validity of this strategy were carried out using the cross sectional samples, and a reduced form model of hours of work. including a correction for sample selection. The results of these tests indicated that the parameter estimates differed by marital status, and that a simple dummy variable indicating married was not sufficient to account for the differences. The results were less strong for the male sample, but significant at the .05 level.

14. The use of the predicted values on the right hand side has important implications for the standard errors derived from the ols regression on hours. The estimated standard errorg from the OLS regression are smaller than the true estimates (Murphy and Topel 1985, Maddala 1983). The derivation of the true standard errors would be quite complex given the nature of tre auxiliary regressions, sample selection and instruments for qualitative varlables, and beyond the scope of this paper.

15. The non-earned income varlable was also used in the panel estimates. The impact of this variable snould be diminished in the panel estimates compared to the cross sectional estimates (Jakubson 1988).

16. Sor exampie, zespondents past experience in 1984 and 1988 are entered into the regression of the 1984 wage.

17. A bivariate probit procedure is preferable, but due to problems of obtaining estimates that would converge using the LIMDEP software and this data set, separate probits were used instead. When bivariate probit estimates could be obtained, the results were virtually identical to those obtained when using the separate probits, even when the correlation of the underlying random variables was significant.

18. For example, a dumy variable was created that indicated whether the person was a current user in both 1984 and 1988 , or had become a current user in 1988 , versus never being a current user, or being a current user in 1984 and not being a current user in 1988. Another variable was a dummy variable that indicated a person became a heavy user in 1988 as compared to 1984 . None of the results from these models differed significantly from those reported in the text. 
Becker, Gary S. "A Theory of the Allocation of Time." Economic Journal $75(1965): 493-517$.

Becker, Gary S., and Murphy, Kevin M. "A Theory of Rational Addiction." Journal of political Economy 96 (August 1988):675-700.

Becker, Gary S.; Grossman, Michael; and Murphy, Kevin M. "An Empirical Analysis of Cigarette Addiction." National Bureau of Economic Research working Paper 3322 (1991).

Browning, Martin. "Jecessary and Sufficient Conditions for Cost Functions." Econometrica 51 (1983):851-856.

Browning, Martin, And Meghir, Costas. "The Effects of Male and Female Labor Supply on Commodity Demands." Econometrica 59 (1991):925-951.

Browning, Uartin; Deaton, Angus; and Irish, Margaret. "A Profitable Approach to Labor Supply and Commodity Demands Over the Life-Cycle." Economertica 53 (May ig85):503-543.

Center for Human Resource Research. NLS Handbook 1990. Columbus: Ohio State University, 1990.

Chaloupka, Frank. "Rational Addictive Behavior and Cigarette Smoking." Journal of Political Economy 99 (1991):722-742.

Chamberlain, Gary. "Panel Data" in Handbook of Econometrics, Vol. 2, edited by $2 v i$ Griliches and Michael Intrilligator. Amsterdam: North Holland, 1984.

Deaton, Angus, and Muelibauer, John. Economics and Consumer Behavior. Cambridge: Cambridge University Press, 1980.

Ghez, G., and Becker, G.S. "A Theory of the Allocation of Time and Goods over the Life Cycle." In The Allocation of Time and Goods over the Life Cycle, edited by G. Ghez and G.S. Becker. New York: Columbia University press, 1975.

Gleason, Philip M.; Veum, Jonathan R.; and Pergamit, Michael R. "Drug and Alcohol Use at work: A Survey of Young Workers." Monthly Labor Review (August 1991):3-7.

Grossman, Michael. "The Economic Analysis of Addicitve Behavior." unpublisned manuscript 1991.

Hammermesh, Daniel S. "Shirking or Productive Schmoozing: Wages and the Allocation of Time At Work." National Bureau of Economic Research, Inc. Working Paper No. 2800, December 1988.

Hayghe, Howard $v$. "Survey of Employer Anti-Drug Programs." In Drugs in the Workplace: Research and Evaluation Data Volume II, edited by Steven W. Gust, J. Michael Walsh, Linda B. Thomas, and Dennis J. Crouch. Washington, D.C.: U.S. Department of Health and Human Services, 1991.

Heckman, James $\mathrm{J}$. "The Common structure of Statistical Models of Truncation, Sample selection and Limited Dependent Variables." Annals of Economic and Social Measurement 5 (Fall 1976):475-92. 
Heckman, James J. "Sample selection Bias as a Specification Error." Econometrica 47 (January 1979):153-161.

Heckman, James J., and Killingsworth, Mark. "Female Labor Supply: A Survey." in Handbook of Labor Economics, edited by Orley Ashenfelter and Richard Layard. Amsterdam: North Holland, 1986.

Hotz, Joseph, and Miller, Robert A. "An Empirical Analysis of Life Cycle Fertility and Female Labor Supply." Econometrica 56 (January 1988):91118.

Jakubson, George. "The Sensitivity of Labor Supply Parameter Estimates to Unobserved Individual Effects: Fixed and Random Effects Estimates in a Non-Linear Model Using Panel Data." Journal of Labor Economics 6 (July 1988): $302-329$.

Johnson, Robert J., and Herring, Cedric. "Labor Market Participation Among Young Adults." Youth and Society 21 (September 1989):3-31.

Kaestner. Robert. "Zhe Effect of Ililicit Drug Use on the Wages of Young Adults." Journa of Labor Economics 9 (October 1991):381-412.

Kagel, John H.; Battalio, Raymond C.; and Miles, C.G. "Marihuana and Work Performance: Resuits From and Experiment." Journal of Human Resources 15 $(1980): 373-395$.

Kandel, Denise B., and Davies, Mark. "Labor Force Experiences of a National Sample of Young Adult Men." Youth and Society 21 (June $1990): 411-445$.

Kandel, Denise B., and Logan, John. "Patterns of Drug Use from Adolesence to Early Adulthood." American Journal of Public Health 74 (July $1984): 660-66$.

Kandel, Denise B., and Yamaguchi, K. "Job Mobility and Drug Use: An Event History Analysis." American Journal of Sociology 92 (1987):836-878.

MaCurdy, Thomas. "An Empirical Model of Labor Supply in a Life-Cycle setting." Journal of Political Economy 89 (December 1981):1059-1085.

Maddala, G.S. Limited Dependent and qualitative Variables in Econometrics. Cambricge, Mass.: Harvard University Press, 1983.

Mensch, Barbara S., and Kandel, Denise B. "Underreporting of Substance Use in a National Longltudinal Youth Cohort." Public Opinion Quarterly 52 $(1988): 100-124$.

Mroz, Thomas. "The Sensitivity of an Empirical Model of Married Women's Hours of Work to Economic and Statistical Assumptions." Econometrica 55 (July 1987): 765-799.

Murphy, Kevin M., and Topel, Robert H. "Estimation and Inference in TwoStep Econometric Models." Journal of Business and Economic Statisticg 3 (October 1985):370-379.

National Institute on Drug Abuse. National Household Survey on Drug Abuse. Rockville, MD.: U.S. Department of Health and Human Services, 1988.

Pollak, R.A. "Conditional Demand Functions and Consumption Theory." Quarterly Journal of Economics 83 (1969):70-78. 
Raveis, V.H., and Kandel, Denise B. "Changes in Drug behavior from the Middle to Late Twenties: Initiation, Persistence, and the Cessation of Use." American Journal of Public Health 77 (1987):607-611.

Stein, Judith A.; Newcomb, Michael D.; and Bentler, P.M. "Structure of Drug Use Behaviors and Consequences Among Young Adults: Multitrait Multimethod Assessment of Frequency, Quantity, Work Site, and Problem Substance Use." Journal of Applied Psychology 73 (1988):595-605.

Stigler, George, and Becker, Gary. "De Gustibue Non Est Disputandum." American Economic Review 67 (March 1977): 76-90.

White, Helene Raskin; Aidala, Angela; and Zablocki, Benjamin. "A Longitudinal Investigation of Drug Use and Work Patterns among Middle Class, White Adults." Journal of Applied Behavioral seience 24 $(1988): 455-469$. 
</ref_section> 
TABLE 1

DISTRIBUTION OF TOTAL SAMPLE BY FREQUENCY OF DRUG USE BY MARITAL STATUS AND GENDER

\begin{tabular}{|c|c|c|c|c|c|c|c|c|c|}
\hline \multirow[b]{2}{*}{ Year } & \multirow{2}{*}{$\begin{array}{l}\text {-ifetime } \\
\text { Erequency of } \\
\text { Cocaine Use }\end{array}$} & \multicolumn{2}{|c|}{$\begin{array}{c}\text { Married } \\
\text { Males }\end{array}$} & \multicolumn{2}{|c|}{$\begin{array}{r}\text { Single } \\
\text { Males }\end{array}$} & \multicolumn{2}{|c|}{$\begin{array}{l}\text { Married } \\
\text { Females }\end{array}$} & \multicolumn{2}{|c|}{$\begin{array}{l}\text { Single } \\
\text { Females }\end{array}$} \\
\hline & & it & i & $N$ & 's & $\mathrm{N}$ & 3 & $N$ & R \\
\hline 1984 & $\begin{array}{r}0 \\
1-9 \\
10-39 \\
40-99 \\
200+\end{array}$ & $\begin{array}{r}555 \\
55 \\
19 \\
13 \\
16\end{array}$ & $\begin{array}{r}84.3 \\
8.4 \\
2.9 \\
2.0 \\
2.4\end{array}$ & $\begin{array}{r}995 \\
118 \\
72 \\
41 \\
44\end{array}$ & $\begin{array}{r}78.3 \\
9.3 \\
5.7 \\
3.2 \\
3.5\end{array}$ & $\begin{array}{r}965 \\
52 \\
21 \\
7 \\
14\end{array}$ & $\begin{array}{r}91.1 \\
4.9 \\
2.0 \\
0.7 \\
1.3\end{array}$ & $\begin{array}{r}1002 \\
37 \\
47 \\
27 \\
23\end{array}$ & $\begin{array}{r}84.5 \\
7.3 \\
4.0 \\
2.3 \\
1.9\end{array}$ \\
\hline 1988 & $\begin{array}{r}0 \\
1-9 \\
: 0-39 \\
10-99 \\
100+\end{array}$ & $\begin{array}{r}706 \\
161 \\
44 \\
24 \\
27\end{array}$ & $\begin{array}{r}73.4 \\
16.7 \\
4.6 \\
2.5 \\
2.8\end{array}$ & $\begin{array}{r}588 \\
188 \\
81 \\
44 \\
49\end{array}$ & $\begin{array}{r}61.9 \\
19.8 \\
8.5 \\
4.6 \\
5.2\end{array}$ & $\begin{array}{r}1011 \\
127 \\
51 \\
17 \\
11\end{array}$ & $\begin{array}{r}83.1 \\
10.4 \\
4.2 \\
1.4 \\
0.9\end{array}$ & $\begin{array}{r}716 \\
145 \\
57 \\
28 \\
21\end{array}$ & $\begin{array}{r}74.0 \\
15.0 \\
5.9 \\
2.9 \\
2.2\end{array}$ \\
\hline & Cocaine Use & $\begin{array}{r}M a \\
M\end{array}$ & $\begin{array}{l}\text { ied } \\
\text { es }\end{array}$ & $\mathrm{Si}$ & $\begin{array}{l}\text { le } \\
\text { Les }\end{array}$ & $\begin{array}{l}\mathrm{Ma} \\
\mathrm{Fe}\end{array}$ & $\begin{array}{l}\text { Eied } \\
\text { ales }\end{array}$ & $\begin{array}{l}\mathrm{Si} \\
\mathrm{Fe}\end{array}$ & $\begin{array}{l}\text { lle } \\
\text { ales }\end{array}$ \\
\hline Year & Past Year & $N$ & के & $\mathrm{N}$ & 8 & $N$ & $\&$ & $\mathbb{N}$ & 8 \\
\hline 1984 & $\begin{array}{ll}(\text { no }) & 0 \\
(y e s) & 1\end{array}$ & $\begin{array}{r}618 \\
40\end{array}$ & $\begin{array}{r}93.9 \\
6.1\end{array}$ & $\begin{array}{r}1060 \\
210\end{array}$ & $\begin{array}{l}83.5 \\
16.5\end{array}$ & $\begin{array}{r}1018 \\
41\end{array}$ & $\begin{array}{r}95.1 \\
3.9\end{array}$ & $\begin{array}{r}1065 \\
121\end{array}$ & $\begin{array}{l}89.8 \\
10.2\end{array}$ \\
\hline 1988 & $\begin{array}{ll}\text { (no) } & 0 \\
\text { (yes) } & 1\end{array}$ & $\begin{array}{r}921 \\
41\end{array}$ & $\begin{array}{r}95.7 \\
4.3\end{array}$ & $\begin{array}{l}838 \\
112\end{array}$ & $\begin{array}{l}88.2 \\
11.8\end{array}$ & $\begin{array}{r}1182 \\
35\end{array}$ & $\begin{array}{r}97.1 \\
2.9\end{array}$ & $\begin{array}{r}901 \\
66\end{array}$ & $\begin{array}{r}93.2 \\
6.8\end{array}$ \\
\hline
\end{tabular}

\begin{tabular}{|c|c|c|c|c|c|c|c|c|c|}
\hline \multirow[b]{2}{*}{ Year } & \multirow{2}{*}{$\begin{array}{l}\text { Eifetime } \\
\text { Erequency of } \\
\text { Marijuana Use }\end{array}$} & \multicolumn{2}{|c|}{$\begin{array}{c}\text { Married } \\
\text { Males }\end{array}$} & \multicolumn{2}{|c|}{$\begin{array}{l}\text { Single } \\
\text { Males }\end{array}$} & \multicolumn{2}{|c|}{$\begin{array}{l}\text { Married } \\
\text { Females }\end{array}$} & \multicolumn{2}{|c|}{$\begin{array}{l}\text { Single } \\
\text { Females }\end{array}$} \\
\hline & & $N$ & 8 & $\mathbf{N}$ & 8 & $\mathbf{N}$ & 8 & $\mathrm{~N}$ & 8 \\
\hline 84 & $\begin{array}{r}0 \\
1-9 \\
10-39 \\
40-99 \\
100+\end{array}$ & $\begin{array}{r}203 \\
163 \\
87 \\
49 \\
156\end{array}$ & $\begin{array}{r}30.9 \\
24.8 \\
13.2 \\
7.4 \\
23.7\end{array}$ & $\begin{array}{l}367 \\
302 \\
122 \\
137 \\
342\end{array}$ & $\begin{array}{r}28.9 \\
23.8 \\
9.6 \\
10.8 \\
26.9\end{array}$ & $\begin{array}{r}482 \\
305 \\
101 \\
71 \\
100\end{array}$ & $\begin{array}{r}45.5 \\
28.8 \\
9.5 \\
6.7 \\
9.4\end{array}$ & $\begin{array}{r}456 \\
341 \\
131 \\
84 \\
174\end{array}$ & $\begin{array}{r}38.4 \\
28.8 \\
11.0 \\
7.1 \\
1.7\end{array}$ \\
\hline & $\begin{array}{r}0 \\
1-9 \\
10-39 \\
40-99 \\
100+\end{array}$ & $\begin{array}{r}299 \\
253 \\
121 \\
84 \\
205\end{array}$ & $\begin{array}{r}31.1 \\
26.3 \\
12.6 \\
8.7 \\
21.3\end{array}$ & $\begin{array}{r}262 \\
254 \\
124 \\
80 \\
230\end{array}$ & $\begin{array}{r}27.6 \\
26.7 \\
13.1 \\
8.4 \\
24.2\end{array}$ & $\begin{array}{r}524 \\
367 \\
142 \\
78 \\
106\end{array}$ & $\begin{array}{r}43.1 \\
30.2 \\
11.7 \\
6.4 \\
8.7\end{array}$ & $\begin{array}{r}346 \\
299 \\
137 \\
58 \\
127\end{array}$ & $\begin{array}{r}35.8 \\
30.9 \\
14.2 \\
6.0 \\
13.1\end{array}$ \\
\hline
\end{tabular}

\begin{tabular}{|c|c|c|c|c|c|c|c|c|c|c|}
\hline \multirow[b]{2}{*}{ Year } & \multicolumn{2}{|c|}{ Marijuana Use } & \multicolumn{2}{|c|}{$\begin{array}{c}\text { Married } \\
\text { Males }\end{array}$} & \multicolumn{2}{|c|}{$\begin{array}{r}\text { Single } \\
\text { Males }\end{array}$} & \multicolumn{2}{|c|}{$\begin{array}{l}\text { Married } \\
\text { Females }\end{array}$} & \multicolumn{2}{|c|}{$\begin{array}{l}\text { Single } \\
\text { Females }\end{array}$} \\
\hline & Past & Year & $N$ & 8 & N & 8 & $\mathrm{~N}$ & 8 & $N$ & 8 \\
\hline 1984 & $\begin{array}{l}(\text { no) } \\
(y e s)\end{array}$ & $\begin{array}{l}0 \\
1\end{array}$ & $\begin{array}{l}455 \\
203\end{array}$ & $\begin{array}{l}69.1 \\
30.9\end{array}$ & $\begin{array}{l}687 \\
583\end{array}$ & $\begin{array}{l}54.1 \\
45.9\end{array}$ & $\begin{array}{l}870 \\
189\end{array}$ & $\begin{array}{l}82.2 \\
17.8\end{array}$ & $\begin{array}{l}823 \\
363\end{array}$ & $\begin{array}{l}69.4 \\
30.6\end{array}$ \\
\hline 1988 & $\begin{array}{l}(\text { no }) \\
\text { yes })\end{array}$ & $\begin{array}{l}0 \\
1\end{array}$ & $\begin{array}{l}805 \\
157\end{array}$ & $\begin{array}{l}83.7 \\
16.3\end{array}$ & $\begin{array}{l}696 \\
254\end{array}$ & $\begin{array}{l}73.3 \\
26.7\end{array}$ & $\begin{array}{r}1123 \\
94\end{array}$ & $\begin{array}{r}92.3 \\
7.7\end{array}$ & $\begin{array}{l}803 \\
164\end{array}$ & $\begin{array}{l}83.0 \\
17.0\end{array}$ \\
\hline
\end{tabular}


TABLE 2

DISTRIBUTION OF EMPLOYED PERSONS BY FREQUENCY OF DRUG USE BY MARITAL STATUS AND GENDER

\begin{tabular}{|c|c|c|c|c|c|c|c|c|c|}
\hline \multirow[b]{2}{*}{ Year } & \multirow{2}{*}{$\begin{array}{l}\text { Lifetime } \\
\text { Frequency }= \\
\text { Cocalne Use }\end{array}$} & \multicolumn{2}{|c|}{$\begin{array}{c}\text { Married } \\
\text { Males }\end{array}$} & \multicolumn{2}{|c|}{$\begin{array}{r}\text { Single } \\
\text { Males }\end{array}$} & \multicolumn{2}{|c|}{$\begin{array}{l}\text { Married } \\
\text { Females }\end{array}$} & \multicolumn{2}{|c|}{$\begin{array}{l}\text { Single } \\
\text { Females }\end{array}$} \\
\hline & & $\mathrm{N}$ & b & $N$ & 's & $\mathrm{N}$ & b & $\mathrm{N}$ & b \\
\hline 1984 & $\begin{array}{r}0 \\
1-9 \\
10-39 \\
40-99 \\
100+\end{array}$ & $\begin{array}{r}535 \\
52 \\
17 \\
12 \\
14\end{array}$ & $\begin{array}{r}84.9 \\
3.3 \\
2.7 \\
1.9 \\
2.2\end{array}$ & $\begin{array}{r}904 \\
111 \\
70 \\
39 \\
42\end{array}$ & $\begin{array}{r}77.5 \\
9.5 \\
6.0 \\
3.3 \\
3.6\end{array}$ & $\begin{array}{r}710 \\
43 \\
18 \\
5 \\
10\end{array}$ & $\begin{array}{r}90.3 \\
5.5 \\
2.3 \\
0.6 \\
1.3\end{array}$ & $\begin{array}{r}748 \\
72 \\
41 \\
22 \\
20\end{array}$ & $\begin{array}{r}82.8 \\
8.0 \\
4.5 \\
2.4 \\
2.2\end{array}$ \\
\hline 988 & $\begin{array}{r}0 \\
1-9 \\
10-39 \\
40-99 \\
100+\end{array}$ & $\begin{array}{r}695 \\
157 \\
44 \\
24 \\
27\end{array}$ & $\begin{array}{r}73.4 \\
16.6 \\
4.6 \\
2.5 \\
2.9\end{array}$ & $\begin{array}{r}542 \\
176 \\
80 \\
42 \\
45\end{array}$ & $\begin{array}{r}61.2 \\
19.9 \\
9.0 \\
4.7 \\
5.1\end{array}$ & $\begin{array}{r}769 \\
106 \\
46 \\
13 \\
7\end{array}$ & $\begin{array}{r}81.7 \\
11.3 \\
4.9 \\
1.4 \\
0.7\end{array}$ & $\begin{array}{r}528 \\
115 \\
53 \\
23 \\
16\end{array}$ & $\begin{array}{r}71.8 \\
15.6 \\
7.2 \\
3.1 \\
2.2\end{array}$ \\
\hline & Cocaine Use & $M a$ & $\begin{array}{l}\text { Eied } \\
\text { les }\end{array}$ & $\mathrm{Si}$ & $\begin{array}{l}\text { gle } \\
\text { les }\end{array}$ & $\begin{array}{l}\text { Mar } \\
\text { Fer }\end{array}$ & $\begin{array}{l}\text { Eied } \\
\text { ales }\end{array}$ & $\begin{array}{l}\text { Sir } \\
\text { Fen }\end{array}$ & $\begin{array}{l}\text { gle } \\
\text { ales }\end{array}$ \\
\hline Year & Past Year & $N$ & 3 & $N$ & h & N & 8 & $N$ & 8 \\
\hline 1984 & $\begin{array}{ll}(\text { no }) & 0 \\
\text { (yes) } & 1\end{array}$ & $\begin{array}{r}592 \\
38\end{array}$ & $\begin{array}{r}94.0 \\
=.0\end{array}$ & $\begin{array}{l}965 \\
201\end{array}$ & $\begin{array}{l}82.8 \\
17.2\end{array}$ & $\begin{array}{r}752 \\
34\end{array}$ & $\begin{array}{r}95.7 \\
4.3\end{array}$ & $\begin{array}{l}801 \\
102\end{array}$ & $\begin{array}{l}38.7 \\
21.3\end{array}$ \\
\hline 988 & $\begin{array}{ll}(\text { no }) & 0 \\
\text { (yes) } & 1\end{array}$ & $\begin{array}{r}907 \\
40\end{array}$ & $\begin{array}{r}95.8 \\
4.2\end{array}$ & $\begin{array}{l}780 \\
105\end{array}$ & $\begin{array}{l}88.1 \\
11.9\end{array}$ & $\begin{array}{r}913 \\
28\end{array}$ & $\begin{array}{r}97.0 \\
3.0\end{array}$ & $\begin{array}{r}683 \\
52\end{array}$ & $\begin{array}{r}92.9 \\
7.1\end{array}$ \\
\hline
\end{tabular}

\begin{tabular}{|c|c|c|c|c|c|c|c|c|c|}
\hline \multirow[b]{2}{*}{ Year } & \multirow{2}{*}{$\begin{array}{l}\text { Lifetime } \\
\text { Frequency oi } \\
\text { Marijuana Use }\end{array}$} & \multicolumn{2}{|c|}{$\begin{array}{l}\text { Married } \\
\text { Males }\end{array}$} & \multicolumn{2}{|c|}{$\begin{array}{l}\text { Single } \\
\text { Males }\end{array}$} & \multicolumn{2}{|c|}{$\begin{array}{l}\text { Married } \\
\text { Females }\end{array}$} & \multicolumn{2}{|c|}{$\begin{array}{l}\text { Single } \\
\text { Females }\end{array}$} \\
\hline & & $N$ & 8 & $N$ & 8 & $\mathrm{~N}$ & 8 & $N$ & 8 \\
\hline 984 & $\begin{array}{r}0 \\
1-9 \\
10-39 \\
40-99 \\
100+\end{array}$ & $\begin{array}{r}197 \\
155 \\
84 \\
47 \\
147\end{array}$ & $\begin{array}{r}31.3 \\
24.6 \\
13.3 \\
7.5 \\
23.3\end{array}$ & $\begin{array}{l}326 \\
277 \\
115 \\
129 \\
319\end{array}$ & $\begin{array}{r}28.0 \\
23.8 \\
9.9 \\
11.1 \\
27.4\end{array}$ & $\begin{array}{r}333 \\
239 \\
79 \\
55 \\
80\end{array}$ & $\begin{array}{r}42.4 \\
30.4 \\
10.1 \\
7.0 \\
10.2\end{array}$ & $\begin{array}{r}323 \\
273 \\
110 \\
70 \\
127\end{array}$ & $\begin{array}{r}28.1 \\
32.1 \\
13.4 \\
9.1 \\
17.3\end{array}$ \\
\hline 988 & $\begin{array}{r}0 \\
1-9 \\
10-39 \\
40-99 \\
100+\end{array}$ & $\begin{array}{r}294 \\
248 \\
119 \\
84 \\
202\end{array}$ & $\begin{array}{r}31.0 \\
26.2 \\
12.6 \\
8.9 \\
21.3\end{array}$ & $\begin{array}{r}237 \\
236 \\
115 \\
76 \\
221\end{array}$ & $\begin{array}{r}26.8 \\
26.7 \\
13.0 \\
8.6 \\
25.0\end{array}$ & $\begin{array}{r}390 \\
292 \\
113 \\
55 \\
91\end{array}$ & $\begin{array}{r}41.4 \\
31.0 \\
12.0 \\
5.8 \\
9.7\end{array}$ & $\begin{array}{r}245 \\
230 \\
107 \\
49 \\
104\end{array}$ & $\begin{array}{r}33.3 \\
31.3 \\
14.6 \\
6.7 \\
14.1\end{array}$ \\
\hline
\end{tabular}

\begin{tabular}{|c|c|c|c|c|c|c|c|c|c|c|}
\hline \multirow[b]{2}{*}{ Year } & \multirow{2}{*}{\multicolumn{2}{|c|}{$\begin{array}{l}\text { Marijuana Use } \\
\text { Past Year }\end{array}$}} & \multicolumn{2}{|c|}{$\begin{array}{c}\text { Married } \\
\text { Males }\end{array}$} & \multicolumn{2}{|c|}{$\begin{array}{l}\text { Single } \\
\text { Males }\end{array}$} & \multicolumn{2}{|c|}{$\begin{array}{l}\text { Married } \\
\text { Females }\end{array}$} & \multicolumn{2}{|c|}{$\begin{array}{l}\text { Single } \\
\text { Females }\end{array}$} \\
\hline & & & $N$ & 8 & $N$ & 8 & $N$ & 8 & $N$ & 8 \\
\hline 1984 & $\begin{array}{l}\text { (no) } \\
\text { (yes) }\end{array}$ & $\begin{array}{l}0 \\
1\end{array}$ & $\begin{array}{l}437 \\
193\end{array}$ & $\begin{array}{l}69.4 \\
30.6\end{array}$ & $\begin{array}{l}623 \\
543\end{array}$ & $\begin{array}{l}53.4 \\
46.6\end{array}$ & $\begin{array}{l}635 \\
151\end{array}$ & $\begin{array}{l}80.8 \\
19.2\end{array}$ & $\begin{array}{l}629 \\
274\end{array}$ & $\begin{array}{l}69.7 \\
30.3\end{array}$ \\
\hline 988 & $\begin{array}{l}\text { (no) } \\
\text { (yes) }\end{array}$ & $\begin{array}{l}0 \\
1\end{array}$ & $\begin{array}{l}791 \\
156\end{array}$ & $\begin{array}{l}83.5 \\
16.5\end{array}$ & $\begin{array}{l}651 \\
234\end{array}$ & $\begin{array}{l}73.6 \\
26.4\end{array}$ & $\begin{array}{r}866 \\
75\end{array}$ & $\begin{array}{r}92.0 \\
8.0\end{array}$ & $\begin{array}{l}601 \\
134\end{array}$ & $\begin{array}{l}81.8 \\
18.2\end{array}$ \\
\hline
\end{tabular}


TABLE 3

AVERAGE ANMUAL HOURS OF WORK AND BOURLY WAGE RATES BY FREQUENCY OF DRUG USE FOR EMPLOYED MARRIED PERSONS

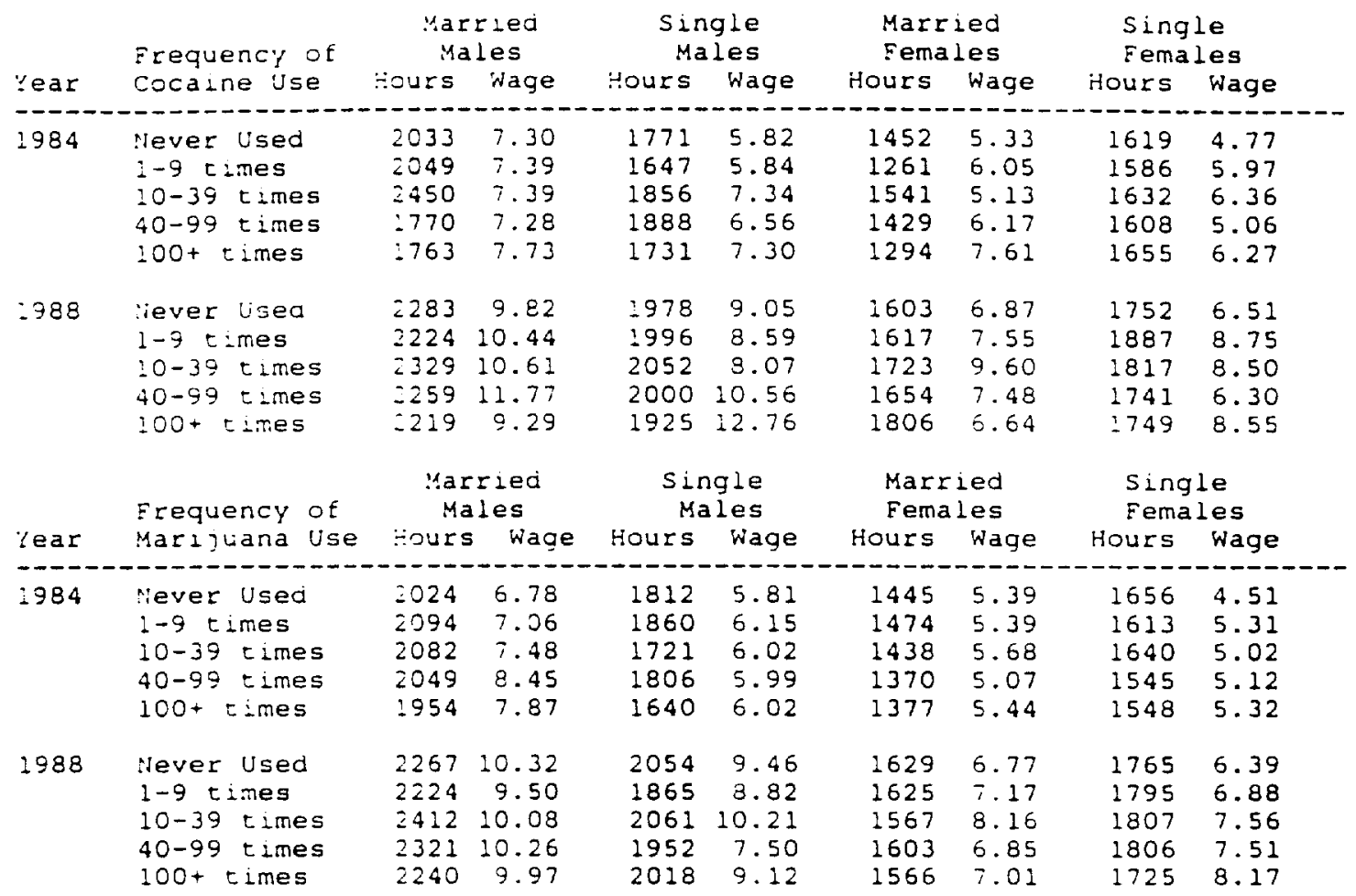


TABLE

PARAMETER ESTIMATES OF THE EFFECT OF ILIICIT DRUG USE ON BOURS WORKED PER YEAR FOR MALES

(standard errors in parentheses)

\begin{tabular}{|c|c|c|c|c|c|c|c|}
\hline \multirow{2}{*}{\multicolumn{2}{|c|}{ Jrug Tipe i }} & \multicolumn{3}{|c|}{$--------1984------------$} & \multicolumn{3}{|c|}{$--------1988--\cdots--------$} \\
\hline & & Total & arried & ingle & Total H & larried s & Single \\
\hline \multicolumn{8}{|c|}{ '-- } \\
\hline-- & $-\infty-\infty$ & & & & & & \\
\hline : & $\begin{array}{l}\text { Iifetime Use } \\
\{0,1,2,3,4\}\end{array}$ & $\begin{array}{l}-60.8+ \\
(37.7)\end{array}$ & $\begin{array}{r}-131.8 * \\
(55.1)\end{array}$ & $\begin{array}{l}-23.1 \\
(43.0)\end{array}$ & $\begin{array}{c}-111.3 * \star \\
(30.9)\end{array}$ & $\begin{array}{l}-87.5 \% \\
(39.5)\end{array}$ & $\begin{array}{c}-127.1 \% \\
(45.4)\end{array}$ \\
\hline 2 & $\begin{array}{l}\text { infetime Use } \\
\text { (midpolnts) }\end{array}$ & $\begin{array}{c}-1.8+ \\
(1.0)\end{array}$ & $\begin{array}{l}-4.1 * \\
(1.5)\end{array}$ & $\begin{array}{l}-0.7 \\
(1.2)\end{array}$ & $\begin{array}{l}-2.9 \star \\
(0.8)\end{array}$ & $\begin{array}{l}-2.5 * \\
(1.1)\end{array}$ & $\begin{array}{l}-2.9 * \\
(1.2)\end{array}$ \\
\hline 3 & $\begin{array}{l}\text { iifetime Use } \\
\text { 1-39 Iimes } \\
\text { iffecime Use } \\
40+\text { Times }\end{array}$ & $\begin{array}{l}-779.3+ \\
(485.7) \\
-313.0 \\
(157.4)\end{array}$ & $\begin{array}{l}-103.7 \\
(633.1) \\
-503.2 \\
(217.1)\end{array}$ & $\begin{array}{l}-587.0 \\
(570.0) \\
-130.2 \\
(186.9)\end{array}$ & $\begin{array}{l}-486.3 \\
(344.9) \\
-432.3 \cdots \\
(126.0)\end{array}$ & $\begin{array}{l}-695.8+ \\
(429.4) \\
-341.8 \\
(155.0)\end{array}$ & $\begin{array}{c}154.7 \\
(483.2) \\
-475.2 \% \\
(187.5)\end{array}$ \\
\hline ; & $\begin{array}{l}\text { Lifecime Use } \\
\text { iO+ Times }\end{array}$ & $\begin{array}{l}-211.2 \\
(143.8)\end{array}$ & $\begin{array}{l}-586.6 \% \\
(204.7)\end{array}$ & $\begin{array}{c}-35.1 \\
(158.4)\end{array}$ & $\begin{array}{l}-378.4 * \\
(110.1)\end{array}$ & $\begin{array}{l}-338.5 * \\
(147.9)\end{array}$ & $\begin{array}{l}-382.1 \\
(153.9)\end{array}$ \\
\hline$\Xi$ & $\begin{array}{l}\text { Current use } \\
(0,2)\end{array}$ & $\begin{array}{l}-219.8 \\
(151.6)\end{array}$ & $\begin{array}{l}-160.8 \\
(232.6)\end{array}$ & $\begin{array}{l}-244.1 \\
(160.8)\end{array}$ & $\begin{array}{l}-571.9 \star \\
(183.6)\end{array}$ & $\begin{array}{l}-440.9 * \\
(212.1)\end{array}$ & $\begin{array}{l}-879.1 * \\
(275.9)\end{array}$ \\
\hline \multicolumn{8}{|c|}{ Cocaine Use } \\
\hline \multicolumn{8}{|c|}{ 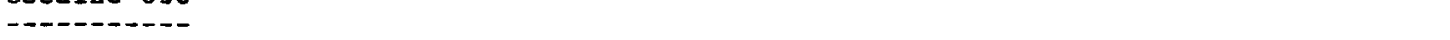 } \\
\hline 1 & $\begin{array}{l}\text { Iifetime Use } \\
(0,1,2,3,4)\end{array}$ & $\begin{array}{c}-7.0 \\
(74.0)\end{array}$ & $\begin{array}{l}-81.6 \\
(97.5)\end{array}$ & $\begin{array}{l}121.0 \\
(84.2)\end{array}$ & $\begin{array}{c}-196.1 \% \\
(59.3)\end{array}$ & $\begin{array}{c}-253.7 * \\
(93.7)\end{array}$ & $\begin{array}{r}-160.0 \\
(72.7)\end{array}$ \\
\hline 2 & $\begin{array}{l}\text { Lifetime Use } \\
\text { (midpoints) }\end{array}$ & $\begin{array}{l}-.09 \\
(2.7)\end{array}$ & $\begin{array}{l}-3.8 \\
(2.8)\end{array}$ & $\begin{array}{c}3.6 \\
(3.2)\end{array}$ & $\begin{array}{l}-7.6 * \\
(2.3)\end{array}$ & $\begin{array}{l}-11.5 \star \\
(3.3)\end{array}$ & $\begin{array}{l}-5.6 \\
(2.8)\end{array}$ \\
\hline 3 & $\begin{array}{l}\text { Lifetime Use } \\
1-9 \text { Times } \\
\text { Iifetime Use } \\
\text { lo+ Times }\end{array}$ & $\begin{array}{c}-322.4 \\
(801.4) \\
176.7 \\
(317.6)\end{array}$ & $\begin{array}{c}-149.6 \\
(930.3) \\
-61.8 \\
(446.0)\end{array}$ & $\begin{array}{c}786.5 \\
(902.6) \\
77.5 \\
(338.1)\end{array}$ & $\begin{array}{l}-722.3+ \\
(450.9) \\
-169.4 \\
(255.1)\end{array}$ & $\begin{array}{c}-1822.8 * \\
(552.9) \\
825.0+ \\
(437.1)\end{array}$ & $\begin{array}{c}770.1 \\
(683.9) \\
-846.6 \\
(306.1)\end{array}$ \\
\hline 4 & $\begin{array}{l}\text { Cifecime Use } \\
10+\text { Timeg }\end{array}$ & $\begin{array}{c}-4.6 \\
(199.6)\end{array}$ & $\begin{array}{l}-154.5 \\
(286.2)\end{array}$ & $\begin{array}{c}202.7 \\
(227.0)\end{array}$ & $\begin{array}{c}-399.9 * \\
(170.4)\end{array}$ & $\begin{array}{l}-150.9 \\
(258.6)\end{array}$ & $\begin{array}{l}-571.2 \% \\
(211.1)\end{array}$ \\
\hline 5 & $\begin{array}{l}\text { Current Use } \\
(0,1)\end{array}$ & $\begin{array}{c}78.2 \\
(210.7)\end{array}$ & $\begin{array}{l}-109.4 \\
(367.1)\end{array}$ & $\begin{array}{c}384.1 \\
(217.9)\end{array}$ & $\begin{array}{l}-916 \cdot 1 * * \\
(283.3)\end{array}$ & $\begin{array}{l}-819.1 * \\
(371.5)\end{array}$ & $\begin{array}{c}-1096.0 * \\
(326.7)\end{array}$ \\
\hline Ob & ations & 1796 & 630 & 1166 & 1832 & 947 & 885 \\
\hline
\end{tabular}

Note: In all models the actual value of drug use is replaced by its predicted value. In models 1 and 2 , the prediction method was an oLs regression. In model 3 , an ordered probit procedure was utilized, and the dumny variables were replaced by the predicted propability of being in each category. In model 4 and 5 , a binary probit model was used to predict the probability of being a current user. All models included the following additional control variables: the predicted value of the natural logarithm of the wage, age, education, the number of children of various ages, race, the predicted value of non-earned income, spouse age, spouse education, and geographic indicators.

- $p<.10$

* $p<.05$ 
TABLE 5

PARAMETER ESTIMATES OF TEE EFFECT OF ILLICIT DRUG USE ON HOURS WORKED PER YEAR FOR FEMALES

(standard errors in parentheses)

\begin{tabular}{|c|c|c|c|c|c|c|c|}
\hline \multicolumn{2}{|c|}{$\begin{array}{l}\text { Drug Type } \\
\text { Model }\end{array}$} & \multicolumn{3}{|c|}{$---------1984 m------n----n$} & \multicolumn{3}{|c|}{ 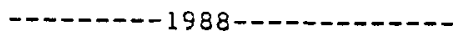 } \\
\hline \multicolumn{8}{|c|}{ Marijuana Use } \\
\hline \multicolumn{8}{|c|}{$---0-------0$} \\
\hline 2 & $\begin{array}{l}\text { Liferime Use } \\
(0,1,2,3,4)\end{array}$ & $\begin{array}{l}-24.1 \\
(34.1)\end{array}$ & $\begin{array}{l}-26.9 \\
(50.6)\end{array}$ & $\begin{array}{l}-19.8 \\
(43.1)\end{array}$ & $\begin{array}{l}-89.2 \star \\
(43.2)\end{array}$ & $\begin{array}{l}24.1 \\
(60.2)\end{array}$ & $\begin{array}{r}-168.1 \% \\
(53.8)\end{array}$ \\
\hline 2 & $\begin{array}{l}\text { Zifetime Use } \\
\text { (midpoincs) }\end{array}$ & $\begin{array}{l}-0.7 \\
(1.0)\end{array}$ & $\begin{array}{l}-1.4 \\
(1.6)\end{array}$ & $\begin{array}{l}-0.5 \\
(1.3)\end{array}$ & $\begin{array}{l}-2.8 \\
(1.4)\end{array}$ & $\begin{array}{c}0.6 \\
(1.9)\end{array}$ & $\begin{array}{l}-4.8 * \\
(1.7)\end{array}$ \\
\hline 3 & $\begin{array}{l}\text { Ifetime Use } \\
\text { 1-39 Times } \\
\text { Iifetime Use } \\
\text { i0+ Times }\end{array}$ & $\begin{array}{c}-278.4 \\
(215.2) \\
-43.5 \\
(140.4)\end{array}$ & $\begin{array}{l}263.3 \\
(299.4) \\
-249.5 \\
(228.8)\end{array}$ & $\begin{array}{c}-410.2 \\
(297.1) \\
-60.6 \\
(169.5)\end{array}$ & $\begin{array}{l}-465.6 \\
(239.8) \\
-175.4 \\
(172.1)\end{array}$ & $\begin{array}{c}-348.8 \\
(312.1) \\
247.3 \\
(270.6)\end{array}$ & $\begin{array}{l}-543.2+ \\
(337.8) \\
-586.5 \\
(205.7)\end{array}$ \\
\hline+ & $\begin{array}{l}\text { Lifetime Use } \\
40+\text { Times }\end{array}$ & $\begin{array}{c}-86.8 \\
(125.3)\end{array}$ & $\begin{array}{l}-327.3+ \\
(181.7)\end{array}$ & $\begin{array}{c}-1 \cdot 3 \\
(158 \cdot 5)\end{array}$ & $\begin{array}{l}-251.1 \\
(166.6)\end{array}$ & $\begin{array}{c}0.5 \\
(227.2)\end{array}$ & $\begin{array}{l}-517.9 * \\
(214.8)\end{array}$ \\
\hline 5 & $\begin{array}{l}\text { Curfent Use } \\
(0,1)\end{array}$ & $\begin{array}{c}5.7 \\
(169.1)\end{array}$ & $\begin{array}{c}10.5 \\
(222.6)\end{array}$ & $\begin{array}{c}40 . i \\
(211.9)\end{array}$ & $\begin{array}{l}-253.0 \\
(235.6)\end{array}$ & $\begin{array}{c}414.7 \\
(374.4)\end{array}$ & $\begin{array}{l}-522.0 \\
(258.5)\end{array}$ \\
\hline \multicolumn{8}{|c|}{ Cocaine Use } \\
\hline \multicolumn{8}{|c|}{-----------} \\
\hline 1 & $\begin{array}{l}\text { Lifetime Use } \\
(0,1,2,3,4)\end{array}$ & $\begin{array}{l}-56.6 \\
(85.3)\end{array}$ & $\begin{array}{l}-132.6 \\
(141.0)\end{array}$ & $\begin{array}{c}-20.6 \\
(100.1)\end{array}$ & $\begin{array}{c}-114.7 \\
(91.7)\end{array}$ & $\begin{array}{l}-117.1 \\
(142.1)\end{array}$ & $\begin{array}{l}-151.7 \\
(105.4)\end{array}$ \\
\hline 2 & $\begin{array}{l}\text { Lifetime Use } \\
\text { (midpoints) }\end{array}$ & $\begin{array}{l}-1.5 \\
(3.4)\end{array}$ & $\begin{array}{l}-4.0 \\
\langle 3.9\rangle\end{array}$ & $\begin{array}{l}-1.6 \\
(3.8)\end{array}$ & $\begin{array}{l}-2.8 \\
(4.3)\end{array}$ & $\begin{array}{l}-3.3 \\
(4.6)\end{array}$ & $\begin{array}{l}-0.5 \\
(4.7)\end{array}$ \\
\hline 3 & $\begin{array}{l}\text { Lifetime Use } \\
1 \text {-9 I imes } \\
\text { Lifetime Use } \\
\text { lo+ Times }\end{array}$ & $\begin{array}{c}-1151.3 \\
(768.0) \\
571.8 \\
(389.3)\end{array}$ & $\begin{array}{c}449.4 \\
(1224.0) \\
-953.1 \\
(869.9)\end{array}$ & $\begin{array}{c}-730.3 \\
(963.8) \\
482.5 \\
(415.6)\end{array}$ & $\begin{array}{c}-107.9 \\
(519.0) \\
37.3 \\
(346.5)\end{array}$ & $\begin{array}{l}128.0 \\
(896.5) \\
-45.4 \\
(782.2)\end{array}$ & $\begin{array}{l}-447.4 \\
(644.4) \\
-353.2 \\
(382.3)\end{array}$ \\
\hline 4 & $\begin{array}{l}\text { Lifetime Use } \\
10+\text { Times }\end{array}$ & $\begin{array}{l}122.8 \\
(216.4)\end{array}$ & $\begin{array}{l}-364.2 \\
(343.1)\end{array}$ & $\begin{array}{l}245.9 \\
(272.9)\end{array}$ & $\begin{array}{c}77.7 \\
(205.8)\end{array}$ & $\begin{array}{l}-83.5 \\
(338.0)\end{array}$ & $\begin{array}{l}-155.7 \\
(229.7)\end{array}$ \\
\hline 5 & $\begin{array}{l}\text { Current Use } \\
(0,1)\end{array}$ & $\begin{array}{c}155.2 \\
(248.8)\end{array}$ & $\begin{array}{l}-287.6 \\
(479.6)\end{array}$ & $\begin{array}{c}86.5 \\
(272.1)\end{array}$ & $\begin{array}{l}-321.5 \\
(375.4)\end{array}$ & $\begin{array}{l}-162.4 \\
(707.3)\end{array}$ & $\begin{array}{c}-600.2+ \\
(358.9)\end{array}$ \\
\hline Obs & ations & 1689 & 786 & 903 & 1676 & 941 & 735 \\
\hline
\end{tabular}

Note: In all models the actual value of drug use is replaced by its predicted value. In models 1 and 2 , the prediction method was an ols regression. In model 3 , an ordered probit procedure was utilized, and the dumny variables were replaced by the predicted probability of being in each category. In models 4 and 5 , a binary probit model was used to predict the probability of being a current user. All models included the following additional control variables: the predicted value of the natural logarithm of the wage, age, education, the number of children of various ages, race, the predicted value of non-earned income, spouse age, spouse education, and geographic indicarors.

$+\quad p<.10$

$* \quad 0<.01$ 
TABLE 6

PARAMETER ESTIMATES OF THE EFPECT OF ILLICIT DRUG USE

ON EOURS WORKED PER YEAR

LONGITUDINAL ESTIMATES FOR MALES AND FEMALES

(standard errorg in parentheses)

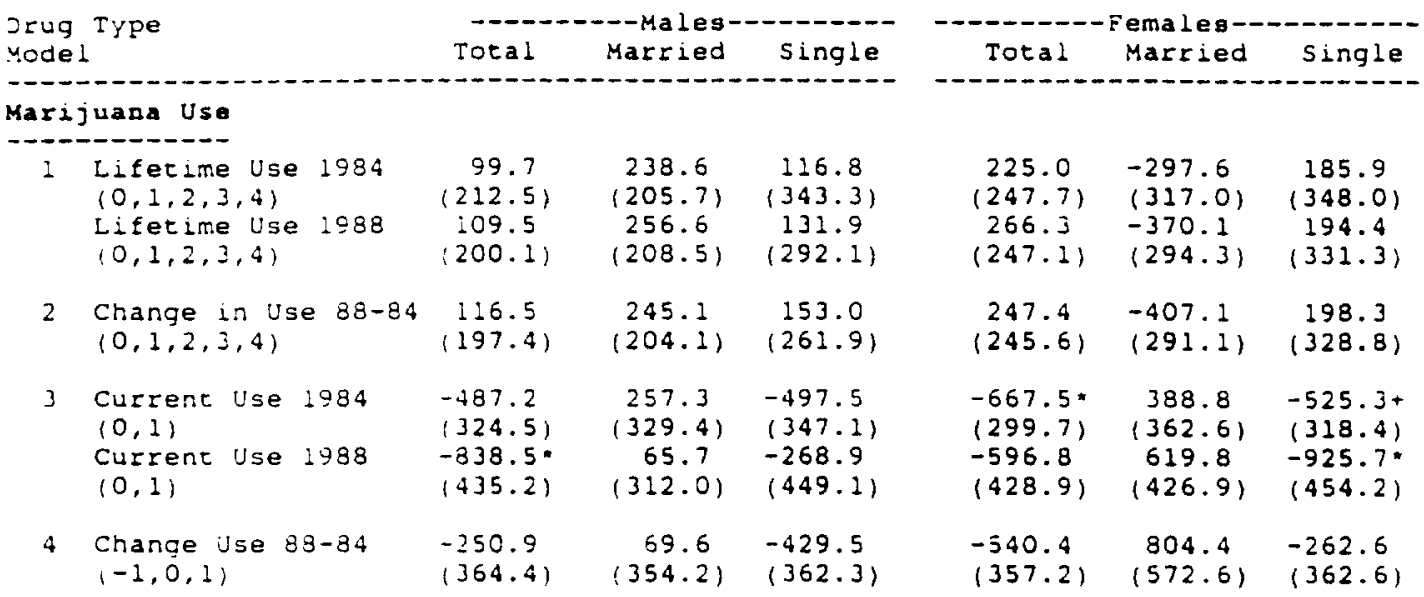

Cocaine Use

\begin{tabular}{|c|c|c|c|c|c|c|c|}
\hline 1 & $\begin{array}{l}\text { Lifetime Use } 1984 \\
(0,1,2,3,4) \\
\text { Lifetime Use } 1988 \\
(0,1,2,3,4)\end{array}$ & $\begin{array}{l}-317.8 * * \\
(280.0) \\
-531.5 * \\
(194.8)\end{array}$ & $\begin{array}{l}-306.8 \\
(263.1) \\
-98.6 \\
(214.9)\end{array}$ & $\begin{array}{c}355.0 \\
(333.8) \\
161.1 \\
(211.5)\end{array}$ & $\begin{array}{c}476.5 \\
(507.8) \\
413.5 \\
(412.8)\end{array}$ & $\begin{array}{l}70.6 \\
(613.8) \\
-181.0 \\
(468.9)\end{array}$ & $\begin{array}{l}201.9 \\
(351.4) \\
236.5 \\
(251.4)\end{array}$ \\
\hline 2 & $\begin{array}{l}\text { Change in Use } 88-84 \\
(0,1,2,3,4)\end{array}$ & $\begin{array}{l}-252.8 \\
(158.1)\end{array}$ & $\begin{array}{l}-81.9 \\
(215.0)\end{array}$ & $\begin{array}{c}37.6 \\
(181.3)\end{array}$ & $\begin{array}{l}336.2 \\
(363.7)\end{array}$ & $\begin{array}{l}-403.1 \\
(419.3)\end{array}$ & $\begin{array}{l}245.1 \\
(246.1)\end{array}$ \\
\hline 3 & $\begin{array}{l}\text { Current Use } 1984 \\
(0,1) \\
\text { Current Use } 1988 \\
(0,1)\end{array}$ & $\begin{array}{l}-450.6 \\
(319.1) \\
-745.1+ \\
(416.7)\end{array}$ & $\begin{array}{c}-91.5 \\
(335.6) \\
454.4 \\
(322.8)\end{array}$ & $\begin{array}{l}-497.5 \\
(347.1) \\
-268.9 \\
(449.1)\end{array}$ & $\begin{array}{l}-696.1 \\
(360.5) \\
-204.1 \\
(485.4)\end{array}$ & $\begin{array}{r}-299.0 \\
(461.2) \\
-1017.8+ \\
(624.9)\end{array}$ & $\begin{array}{l}-525.3+ \\
(318.4) \\
-925.7 \\
(454.2)\end{array}$ \\
\hline 4 & $\begin{array}{l}\text { Change in Use } 88-84 \\
(-1,0,1)\end{array}$ & $\begin{array}{l}-235.5 \\
(474.8)\end{array}$ & $\begin{array}{l}730.2 \\
(567.7)\end{array}$ & $\begin{array}{r}906.1+ \\
(556.8)\end{array}$ & $\begin{array}{l}-172.7 \\
(562.7)\end{array}$ & $\begin{array}{l}1366.3 \\
(879.4)\end{array}$ & $\begin{array}{l}-416.5 \\
(574.8)\end{array}$ \\
\hline & tions & 1490 & 380 & 501 & 1276 & 423 & 371 \\
\hline
\end{tabular}

Note: In all models the actual value of drug use is replaced by its predicted value. In models 1,2 and 4 , the prediction method was an ols regression. In model 3 , a binary probit model was used to predict the probability of being a current user. All models included the following additional control variableg: the predicted value of the natural logarithm of the wage, age, education, the number of children of various agea, race, the predicted value of non-earned income, spouse age, spouse education, and geographic indicators. For time varying variableg (e.g. children), both the 1984 and 1988 values were entered into the model. Also the signs on the 1984 variables have been switched, since the software package assumes an additive form.

$+p<.10$

* p<.05

- $p<.01$ 


\section{APPENDIX TABLE 1 MEAN VALUES OF VARIABLES USED IN ANALYSIS MARRIED SAMPLE}

\begin{tabular}{|c|c|c|c|c|}
\hline \multirow[b]{2}{*}{ Variable } & \multicolumn{2}{|c|}{1984} & \multicolumn{2}{|c|}{1988} \\
\hline & $\begin{array}{l}\text { Male } \\
\text { Mean }\end{array}$ & $\begin{array}{c}\text { Female } \\
\text { Mean }\end{array}$ & $\begin{array}{l}\text { Male } \\
\text { Mean }\end{array}$ & $\begin{array}{c}\text { Female } \\
\text { Mean }\end{array}$ \\
\hline Black & 0.144 & 0.129 & 0.180 & 0.152 \\
\hline Hispanic & 0.164 & 0.273 & 0.149 & 0.161 \\
\hline $\mathrm{AFQT}$ & 64.650 & 66.902 & 65.380 & 67.408 \\
\hline Experience & 241.725 & 173.188 & 415.806 & 318.944 \\
\hline Age & 24.595 & 24.305 & 28.715 & 28.730 \\
\hline Education & 11.839 & 12.152 & 12.077 & 12.286 \\
\hline Spouse Age & 23.099 & 26.769 & 26.965 & 31.153 \\
\hline Spouse Educ & 12.090 & 12.295 & 12.514 & 12.548 \\
\hline Num Chil Age $0-2$ & 0.371 & 0.409 & 0.326 & 0.303 \\
\hline Num Chil Age 3-5 & 0.299 & 0.373 & 0.432 & 0.472 \\
\hline Num chil Age $6-17$ & 0.161 & 0.209 & 0.499 & 0.735 \\
\hline Religion & 2.965 & 3.220 & 2.957 & 3.231 \\
\hline Self Esteem Scale & 32.757 & 32.258 & 32.628 & 32.280 \\
\hline Rotter Scale & 8.723 & 8.725 & 8.629 & 8.632 \\
\hline Num Illegal ACts & 10.699 & 3.318 & 10.710 & 3.349 \\
\hline Two Par Áge 14 & 0.825 & 0.812 & 0.831 & 0.823 \\
\hline Two Par Age 18 & 0.629 & 0.612 & 0.662 & 0.637 \\
\hline Mother's Education & 9.869 & 10.001 & 9.894 & 10.074 \\
\hline Live with Parents & 0.043 & 0.042 & 0.019 & 0.036 \\
\hline Urban & 0.676 & 0.739 & 0.700 & 0.740 \\
\hline Unemployment Rate & 3.514 & 3.538 & 2.624 & 2.658 \\
\hline North East Reg & 0.138 & 0.155 & 0.160 & 0.187 \\
\hline North Central Reg & 0.295 & 0.260 & 0.267 & 0.242 \\
\hline Southern Reg & 0.403 & 0.398 & 0.388 & 0.389 \\
\hline Miss Mother's Ed & 0.070 & 0.045 & 0.077 & 0.045 \\
\hline Miss Experience & 0.021 & 0.015 & 0.072 & 0.045 \\
\hline Observations & 658 & 1059 & 962 & 1217 \\
\hline
\end{tabular}


APPENDIX TABLE 2

MEAN VALUES OF VARIABLES USED IN ANALSIS

SINGLE SAMPLE

\begin{tabular}{|c|c|c|c|c|}
\hline \multirow{2}{*}{ Variable } & \multicolumn{2}{|c|}{1984} & \multicolumn{2}{|c|}{1988} \\
\hline & $\begin{array}{l}\text { Male } \\
\text { Mean }\end{array}$ & $\begin{array}{c}\text { Female } \\
\text { Mean }\end{array}$ & $\begin{array}{l}\text { Male } \\
\text { Mean }\end{array}$ & $\begin{array}{c}\text { Female } \\
\text { Mean }\end{array}$ \\
\hline lack & 0.353 & 0.379 & 0.375 & 0.416 \\
\hline Hispanic & 0.161 & 0.124 & 0.179 & 0.133 \\
\hline AFQT & 58.723 & 59.465 & 57.219 & 58.144 \\
\hline Experience & 194.287 & 162.804 & 339.579 & 281.819 \\
\hline Age & 23.739 & 23.964 & 28.246 & 28.511 \\
\hline Education & 11.857 & 12.056 & 11.702 & 11.912 \\
\hline Num chil age $0-2$ & 0.032 & 0.182 & 0.053 & 0.132 \\
\hline Num Chil Age $3-5$ & 0.019 & 0.259 & 0.064 & 0.300 \\
\hline Num Chil Age $6-17$ & 0.004 & 0.218 & 0.059 & 0.677 \\
\hline Religion & 2.820 & 3.187 & 2.746 & 3.210 \\
\hline Self Esteem Scale & 32.137 & 31.537 & 32.017 & 31.532 \\
\hline Rotter Scale & 8.669 & 8.977 & 8.778 & 8.951 \\
\hline Num Illegal Acts & 14.005 & 6.077 & 13.196 & 5.994 \\
\hline Two Par Age 14 & 0.733 & 0.718 & 0.719 & 0.678 \\
\hline Two Par Age 18 & 0.598 & 0.564 & 0.576 & 0.519 \\
\hline Mother's Education & 9.705 & 9.895 & 9.464 & 9.620 \\
\hline Live With Parents & 0.587 & 0.431 & 0.346 & 0.217 \\
\hline Urban & 0.795 & 0.799 & 0.811 & 0.792 \\
\hline Unemployment Rate & 3.385 & 3.363 & 2.595 & 2.578 \\
\hline North East Reg & 0.202 & 0.200 & 0.194 & 0.174 \\
\hline North Central Reg & 0.231 & 0.239 & 0.223 & 0.240 \\
\hline Southern Reg & 0.380 & 0.394 & 0.399 & 0.419 \\
\hline Miss Mother's Ed & 0.072 & 0.049 & 0.081 & 0.057 \\
\hline Miss Experience & 0.028 & 0.018 & 0.102 & 0.052 \\
\hline Observations & 1270 & 1186 & 950 & 967 \\
\hline
\end{tabular}


APPENDIX TABLE 3

PARAMETER ESTIMATES FROM MODEL OF ANWUAI HOURS OF WORX CROSS SECTIONAL ESTIMATES

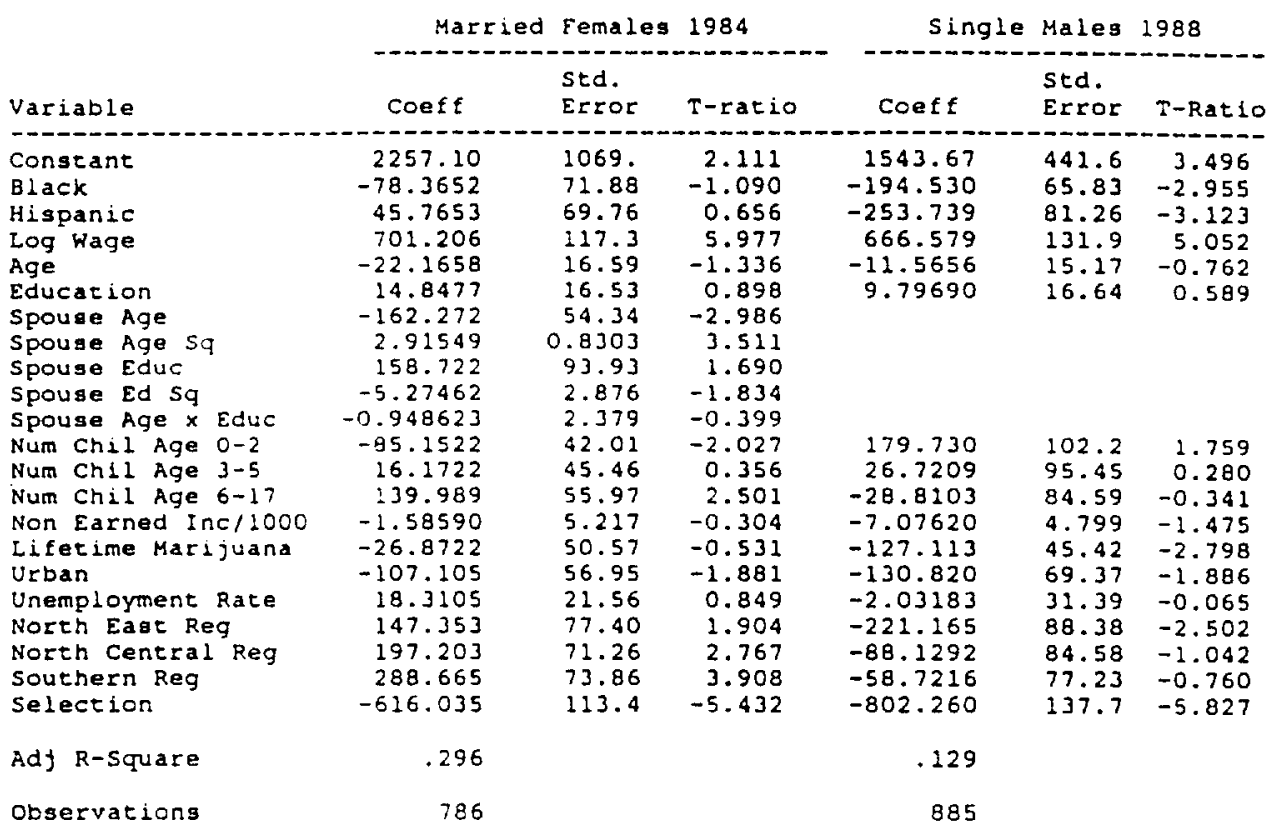

Note: Predicted values are used as instrumentg for the log wage, drug uge, and non earned income. Lifetime marijuana use is a linear measure with values ranging from 0 to 4. The selection variable is the inverse millg ratio derived from probit estimates of the probability of being employed dusing lagt year. The atandard errors reported in the table have been corrected to take account of the selection term, but not the use of the other predicted values, and are thus only approximations of the true atandard errors. Parameter estimates from other models are available from the author. 
APPENDIY TABLE \&

PARAMETER ESTIMATES FROM MODELS OF ILIICIT DRUG USE

\begin{tabular}{|c|c|c|c|c|c|c|}
\hline Variable & \multicolumn{2}{|c|}{$\begin{array}{c}\text { Lifetime Marijuana } \\
\text { Married } \\
\text { Femaleg } 1904\end{array}$} & \multicolumn{2}{|c|}{$\begin{array}{c}\text { Current Marijuana } \\
\text { Single } \\
\text { Males } 1988\end{array}$} & $\begin{array}{l}\text { Lifetime cocaino } \\
\text { Married } \\
\text { Maleg } 1988\end{array}$ & $\begin{array}{l}\text { Cocaina } \\
\text { Led } \\
1988 \\
\text { std. } \\
\text { Error }\end{array}$ \\
\hline 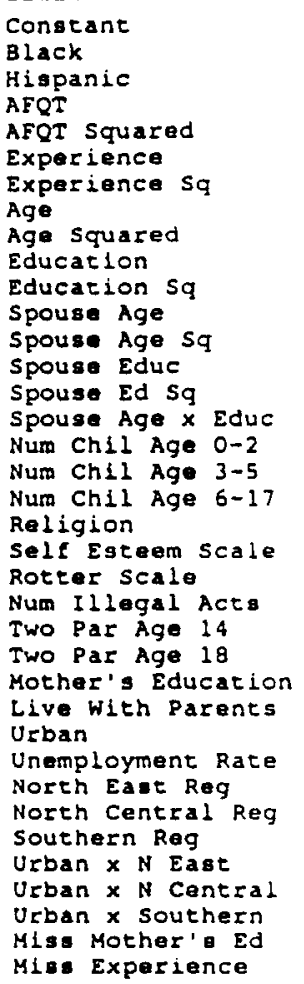 & $\begin{array}{r}6.52240 \\
-0.03710 \\
-0.23263 \\
0.01303 \\
-0.00002 \\
0.00344 \\
-0.00010 \\
-0.56366 \\
0.01037 \\
-0.01100 \\
-0.00115 \\
0.12504 \\
-0.00215 \\
0.05157 \\
-0.00472 \\
0.00200 \\
-0.02297 \\
-0.00606 \\
-0.13453 \\
-0.16422 \\
0.00020 \\
0.01325 \\
0.01509 \\
-0.14219 \\
-0.23446 \\
0.03379 \\
-0.06478 \\
0.04973 \\
-0.08060 \\
-0.61480 \\
-0.50664 \\
-0.62373 \\
0.49818 \\
0.32388 \\
0.14869 \\
0.00566 \\
0.29443\end{array}$ & $\begin{array}{l}7.58500 \\
0.12880 \\
0.11840 \\
0.01202 \\
0.00009 \\
0.00131 \\
0.00003 \\
0.61930 \\
0.01278 \\
0.15470 \\
0.00629 \\
0.08293 \\
0.00113 \\
0.16570 \\
0.00520 \\
0.00427 \\
0.06511 \\
0.07100 \\
0.08062 \\
0.02270 \\
0.01018 \\
0.01579 \\
0.00311 \\
0.11180 \\
0.09289 \\
0.01485 \\
0.18270 \\
0.27510 \\
0.03479 \\
0.36070 \\
0.29290 \\
0.28450 \\
0.38080 \\
0.31270 \\
0.30070 \\
0.22640 \\
0.31330\end{array}$ & $\begin{array}{r}-0.10377 \\
-0.02751 \\
-0.14574 \\
-0.07977 \\
-0.00524 \\
-0.00275 \\
0.00214 \\
-0.10531 \\
-0.05565 \\
0.04072 \\
-0.03757 \\
0.73310 \\
0.05468 \\
0.52612 \\
0.08574 \\
0.55263 \\
-0.77240 \\
-0.29821 \\
-0.68170 \\
0.30234 \\
0.20889\end{array}$ & $\begin{array}{l}0.21050 \\
0.19730 \\
0.16050 \\
0.03002 \\
0.01264 \\
0.02065 \\
0.00108 \\
0.12600 \\
0.12500 \\
0.01883 \\
0.09919 \\
0.63370 \\
0.05625 \\
0.69280 \\
0.66230 \\
0.63880 \\
0.70790 \\
0.68000 \\
0.65160 \\
0.25250 \\
0.28030\end{array}$ & $\begin{array}{r}-4.35475 \\
-0.09345 \\
-0.13346 \\
-0.00476 \\
0.00008 \\
0.00230 \\
-0.00000 \\
0.26491 \\
-0.00418 \\
0.12547 \\
-0.00739 \\
0.00892 \\
0.00008 \\
0.00043 \\
0.00453 \\
-0.00220 \\
0.04553 \\
-0.00394 \\
-0.02300 \\
-0.06148 \\
-0.01125 \\
0.00864 \\
0.00215 \\
0.01626 \\
-0.05791 \\
0.03513 \\
0.10233 \\
0.24051 \\
-0.01243 \\
-0.34221 \\
-0.45679 \\
-0.35245 \\
0.09636 \\
-0.20429 \\
-0.17963 \\
0.29676 \\
0.28793\end{array}$ & $\begin{array}{l}0.43600 \\
0.09213 \\
0.09538 \\
0.00785 \\
0.00006 \\
0.00125 \\
0.00000 \\
0.59170 \\
0.01030 \\
0.11800 \\
0.00479 \\
0.06791 \\
0.00098 \\
0.13930 \\
0.00472 \\
0.00433 \\
0.05529 \\
0.04748 \\
0.04158 \\
0.01744 \\
0.00801 \\
0.01220 \\
0.00100 \\
0.08684 \\
0.06907 \\
0.01227 \\
0.21010 \\
0.20990 \\
0.03731 \\
0.25750 \\
0.21790 \\
0.22410 \\
0.27200 \\
0.23560 \\
0.22900 \\
0.15540 \\
0.26280\end{array}$ \\
\hline Adj. R-Square & .152 & & & & .11 & \\
\hline servations & 1059 & & 950 & & 962 & \\
\hline
\end{tabular}

Note: The parameter estimates for the models of lffetime marlfuana and cocaine use were obtained by OLS regressions, and the dependent variables had a range of values between 0 and 4. The parameter estimates of the model of current (1.e. past year) marijuana use were obtained by a maximum likelihood probit model, and the dependent variable was binary. parameter estimates from other models are available from the author. 
APPENDII TABLE 5

PARAMETER ESTIMATES FROM MODEL OF ANNUAL HOURS OF WORK PANEL DATA ESTIMATES

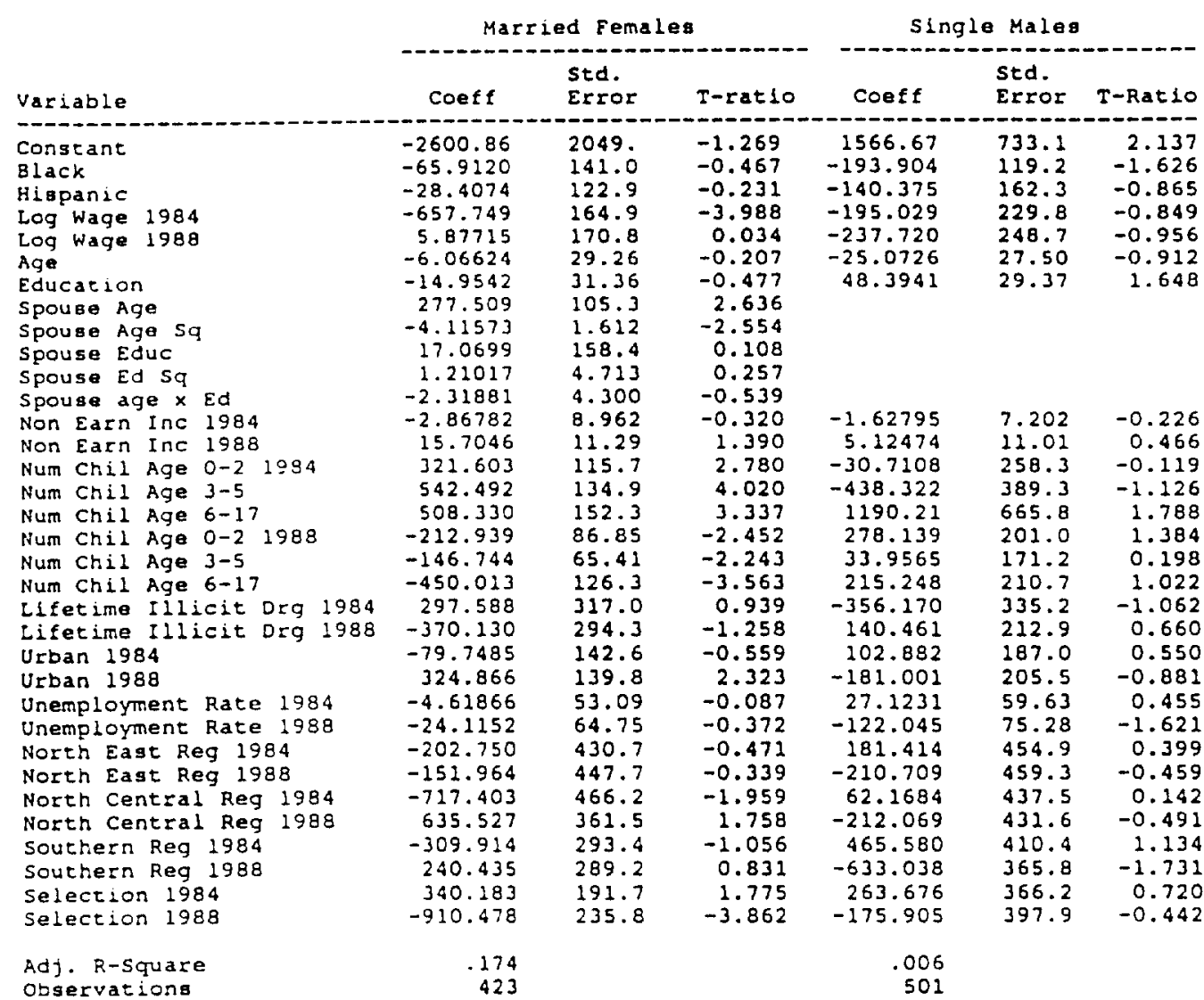

Note: The illicit drug included in the married female model is marljuana, and in the oingle male model the illicit drug was cocaine. Both of these measures are linear with values ranging from 0 to 4. Predicted values are used as ingtrumente for the log wage, dzug use, and non earned income. The gelection variable is the inverse millg ratio derived from problt estimates of the probability of being employed during last year.

The standard errors reported in the table have not been corrected to take account of the selection term, or the uge of the other predicted values, and are thus only approximations of the true standard errors. Parameter estimates from other modela are avallable from the auchor. 